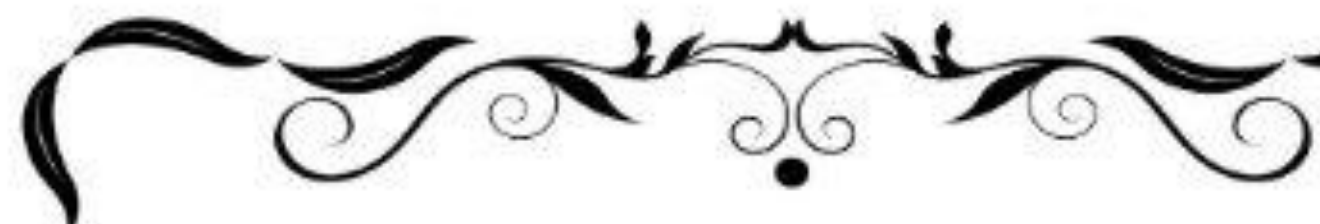

\title{
الاحتياجات الإرشادية للموهوبين في الجاهعات السعودية
}

Counseling needs of the gifted in Saudi universities

$$
\text { إعلاد }
$$

د. نوف نوار محسن العتيبي

Dr. Nouf Nawar Mohsen Al-Otaibi

أستاذ مساعد بقسم التربية الخاصة - جامعة نجران

Doi: 10.21608/jasht.2022.212161

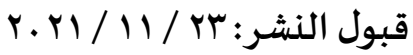

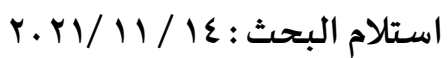

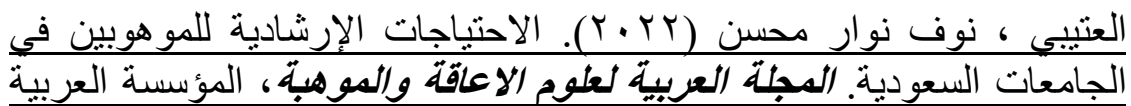

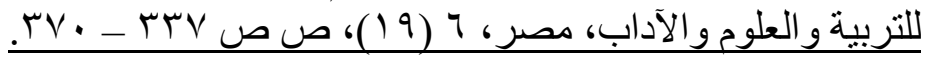

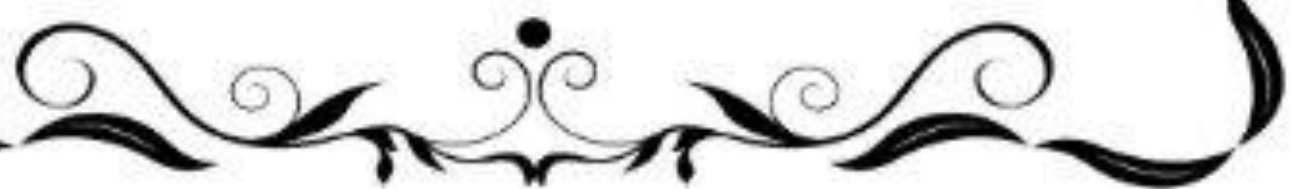




\section{الاحتياجات الإرشادية للموهوبين في الجامعات السعودية}

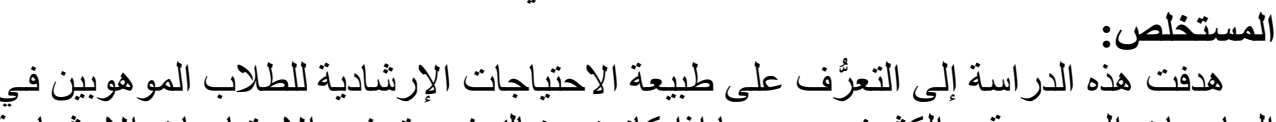

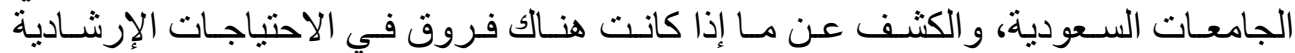

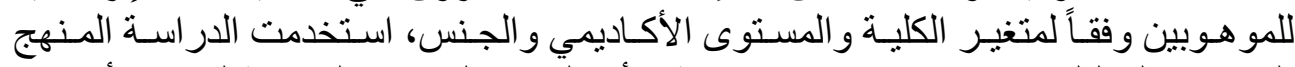

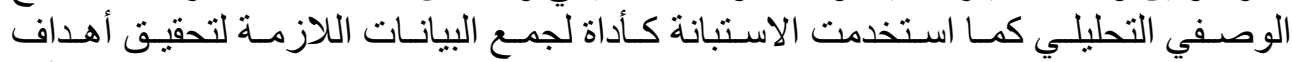

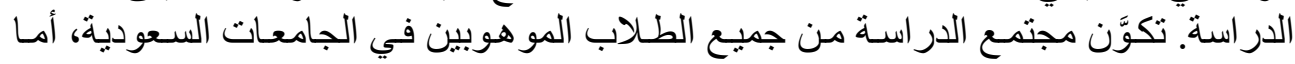

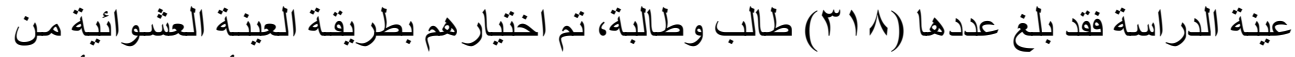

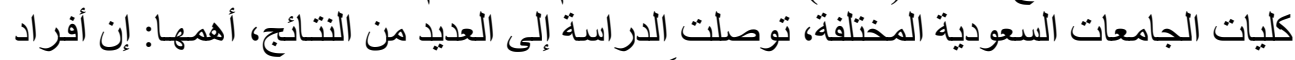

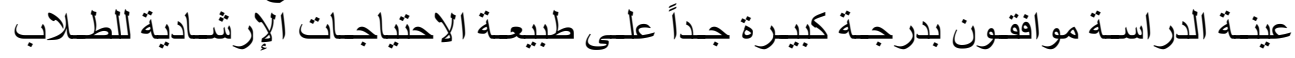

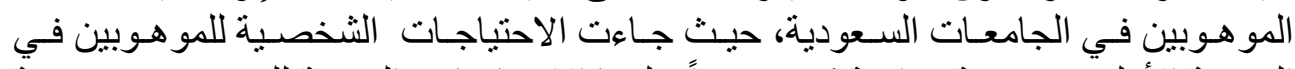

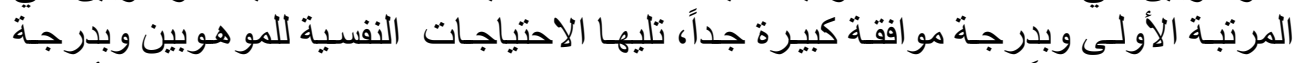

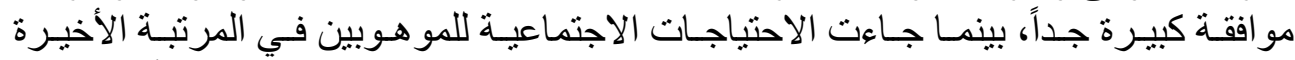
وبدرجة مو افقة كبيرة. كما كثفت النتائج عن وجود فروق إحصائية في استجابات أفراد اد عينة

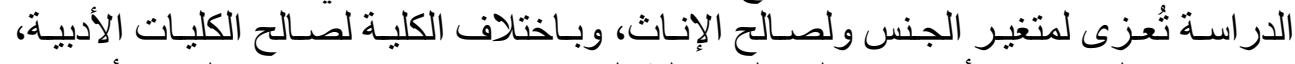

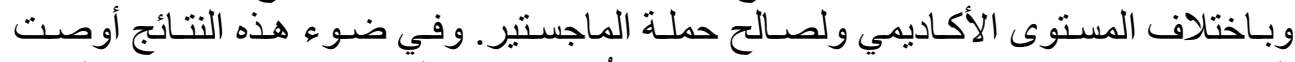

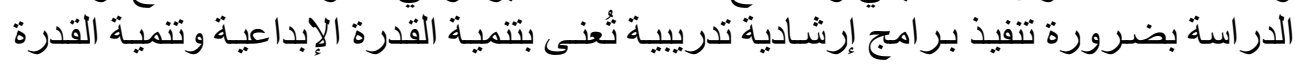
على مو اجهة المشكلات الاجتماعية وتتمية مستوى الطموح لدى الطلاب المو هوبين). الكلمات المفتاحية: الاحتياجات الإرشادية، الطلاب المو هوبين، الجامعات السعودية.

\section{Abstract:}

This study aimed to identify the nature of the guidance needs of gifted students in Saudi universities, and to reveal whether there are differences in the guidance needs of the gifted according to college, academic level, and gender variable. The researcher used the descriptive and analytical approach. The researcher also used the questionnaire as a tool to collect data required to achieve the study objectives. The study population consisted of all gifted students in Saudi universities. The sample of the study was (318) male and female students, who were selected by random sampling method from the faculties of different Saudi universities. The study reached many results, the most important of which are: the study sample members agreed with "strongly agree" degree on the nature of the guidance 
needs of gifted students in Saudi universities. The personal needs of the gifted students came in the first place with a "strongly agree", followed by the psychological needs of the gifted student with a "strongly agree" degree, while the social needs of the gifted student came in the last rank and with a "agree" degree. The results also revealed that there were statistically significant differences in the responses of the study sample members due to the gender variable in favor of females, and the difference in college in favor of literary colleges. In light of these results, the study recommended the necessity of implementing guidance and training programs concerned with building creative capacity, developing the ability to face social problems, and developing the level of ambition among gifted students. Keywords: Guidance Needs, Gifted Students, Saudi Universities.

ثُعد المرة حلة الجامعية من المر احل التعليمبـة المهمهة و الأساسية، إذ تعمل على بنـاء شخصية

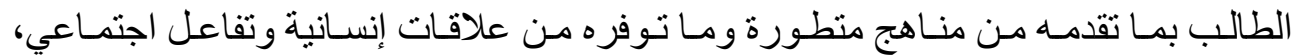

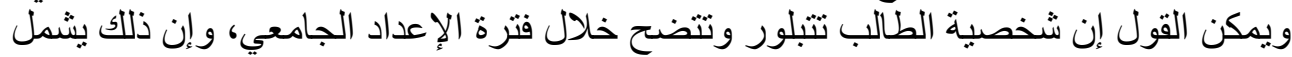

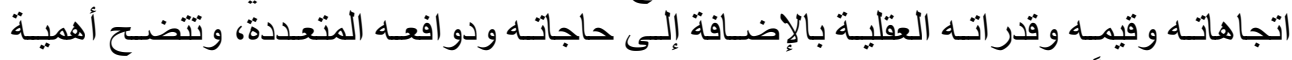

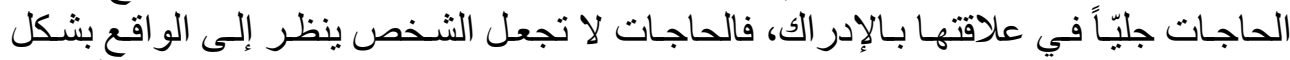

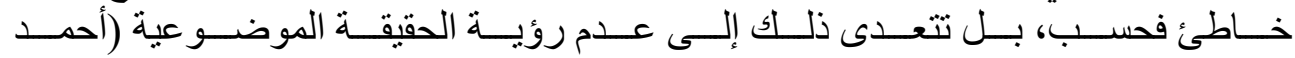

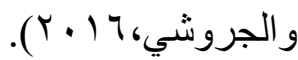
يُعتبـر تقيـيم الحاجـات الإرشــادية لأي شـريحة اجتمـاعيـة، الخطـوة الأساسـية لبنـاء برنـامج

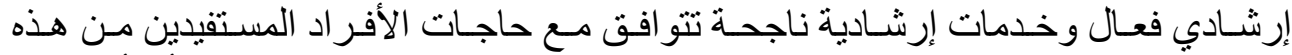

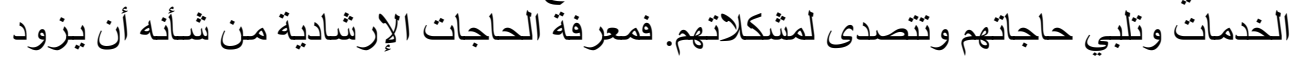

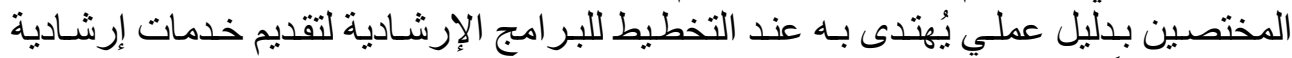

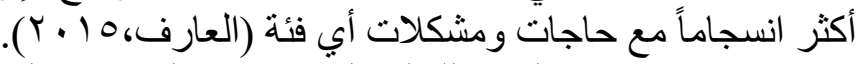
تهدف بر امج الإرشاد المعدة للطلبة المو هوبين والمتفوقين إلى مسـاعدتهم على النمو السوي و التكيف الإيجابي في المجالات الانفعالية والمعرفية و المهنية، بالإضافة إلى مساعدة الو الدين

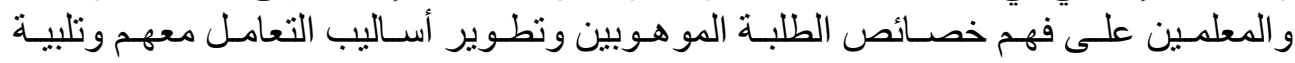

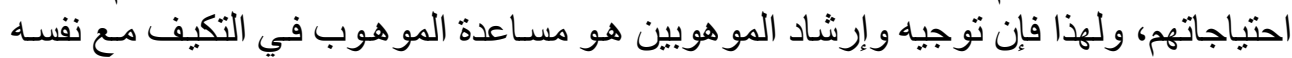

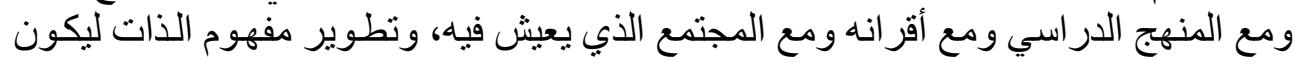




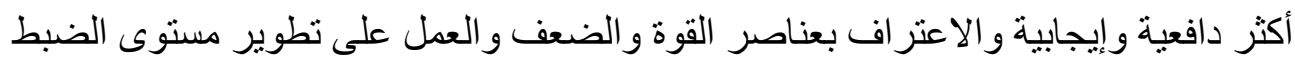

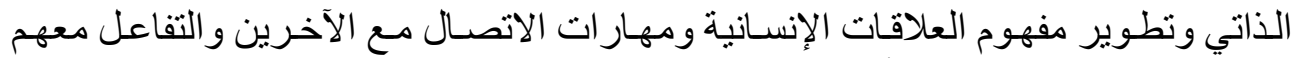

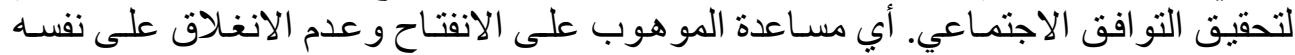

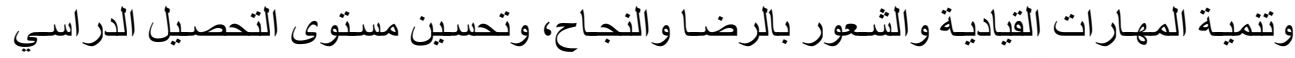

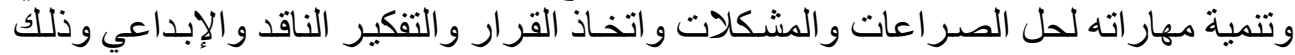

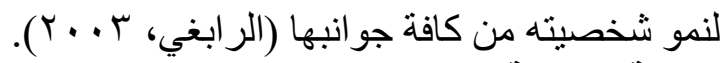
مشكلة الاراسة: مئه إن الاهتمام بالمو هوبين جاء في إطار اهتمامات علم النفس الإيجابي الذي بهتم بإنم باستثمار

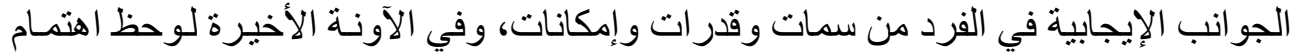

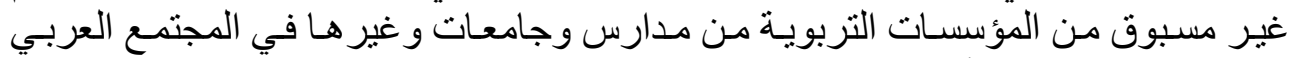

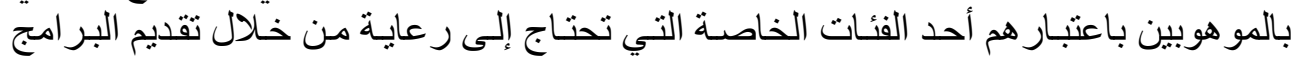

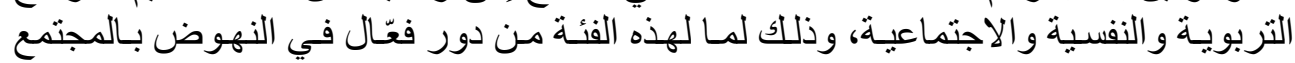

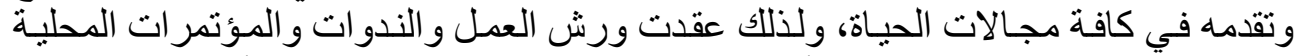

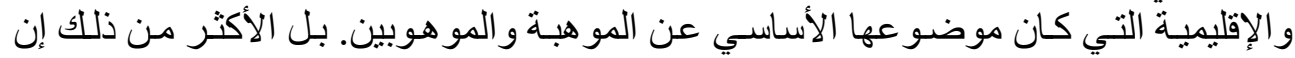

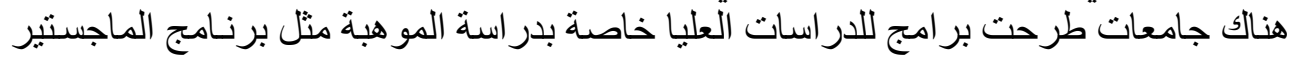

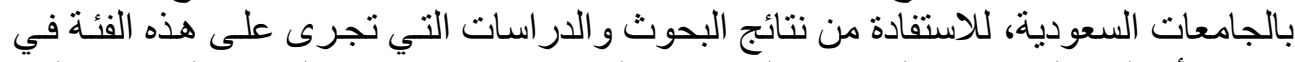

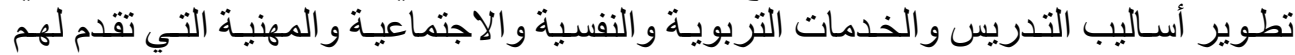

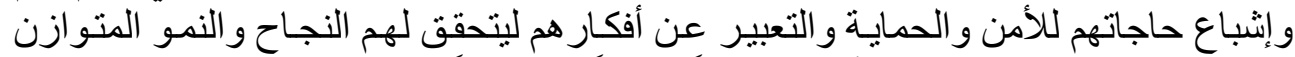

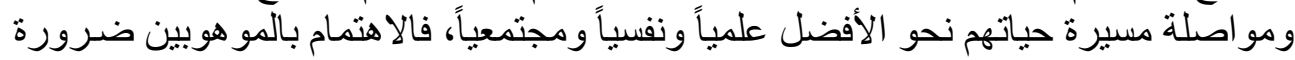

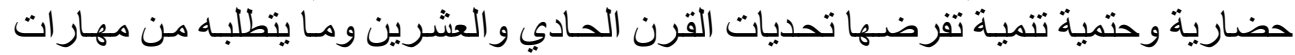

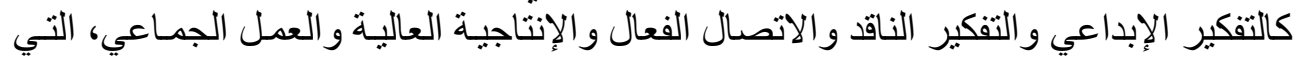

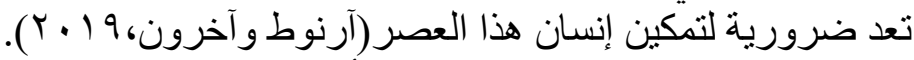

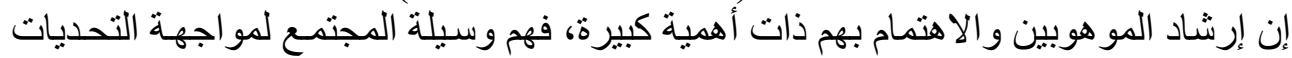

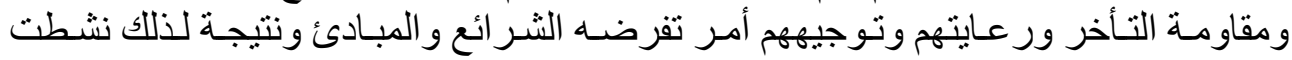

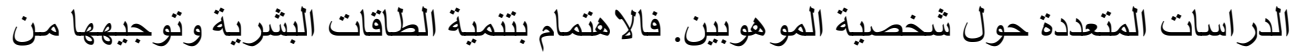

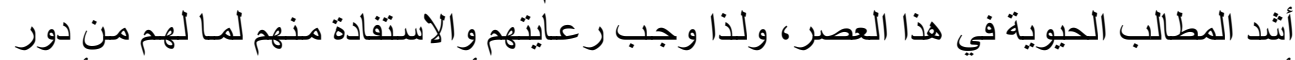

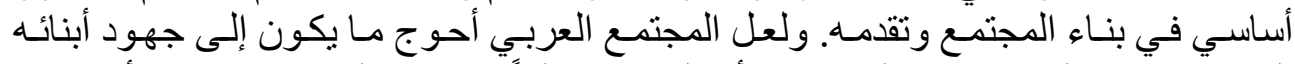

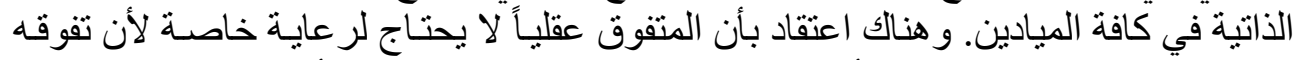

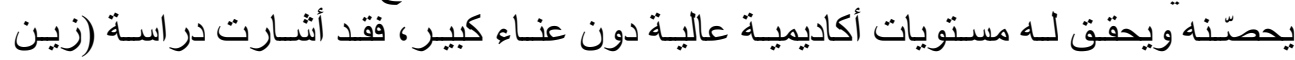

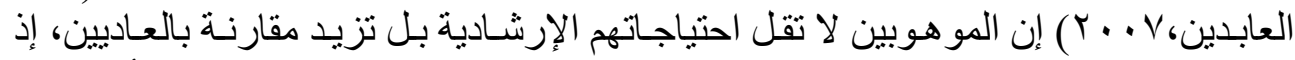

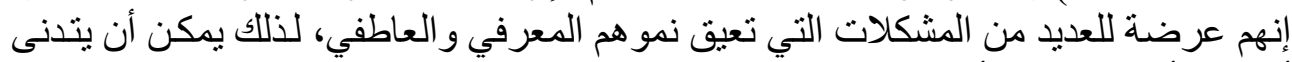

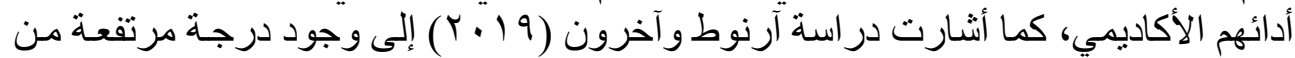




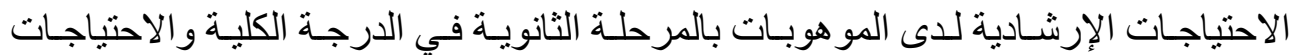

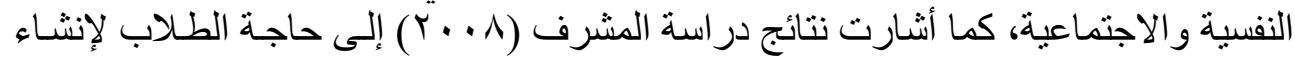

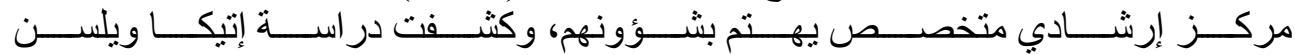
Atik.G,Yalcin,I,2010" الأكاديمي و العلاقات والانفعالات والجو انب المهنية.

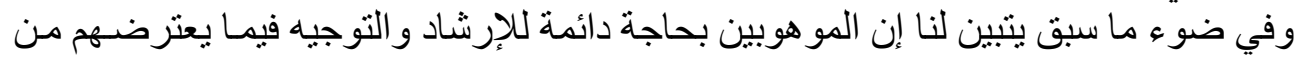

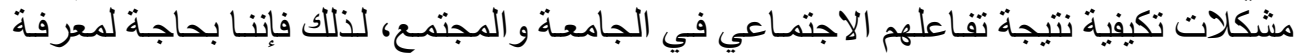

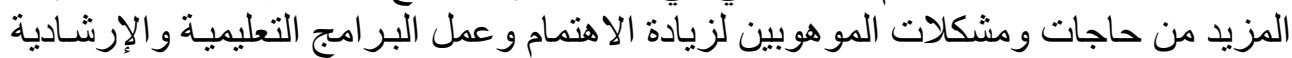

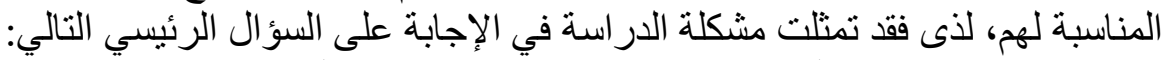
ما الاحتياجات الإرشادية للموهوبين في الجامعات السعودية: مئه

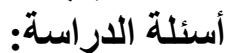
يتفرع من السؤال الرئيسي الأسئلة الفرعية التالية:

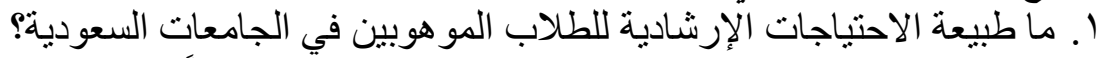

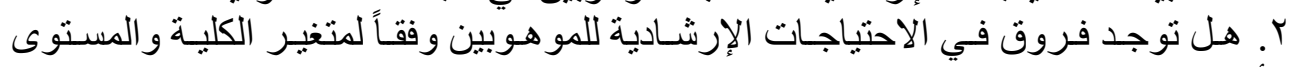
الأكاديمي و الجنس؟

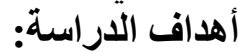

ا. التعرف على طبيعة الاحتياجات الإرشادية للطلاب المو هوبين في الجامعات السعودية.

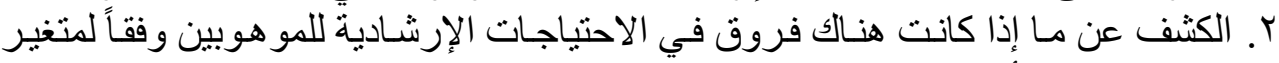
الكلية و المستوى الأكاديمي و الجنس. أهمية الار استة: الأنية

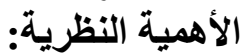

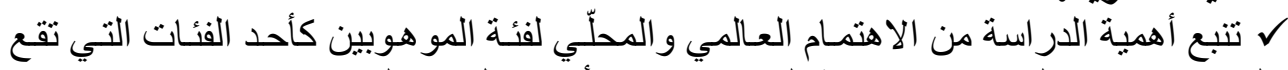

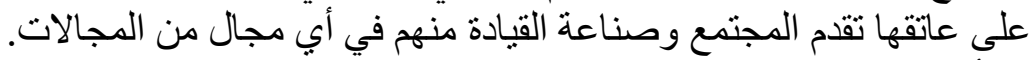

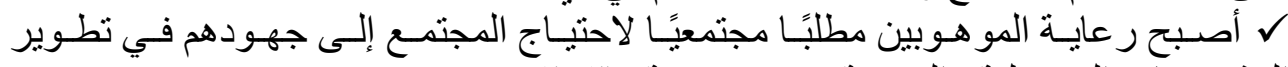

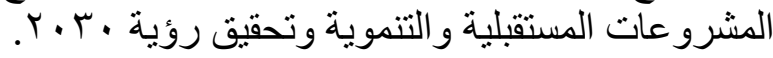

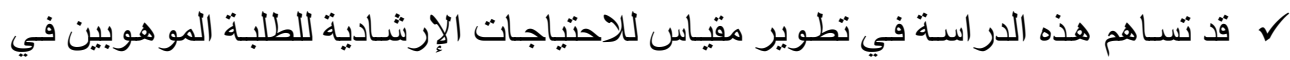

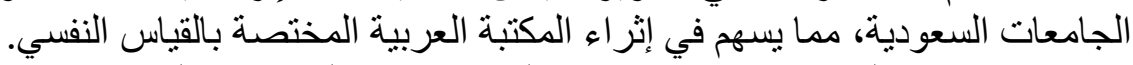

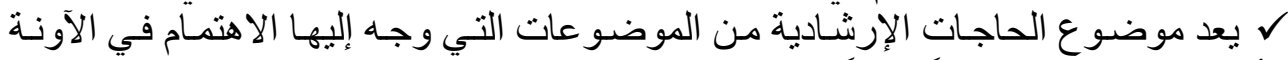

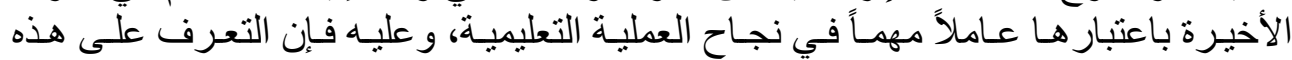

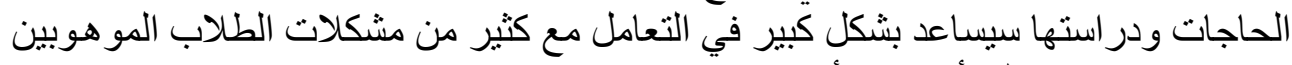
مما ينعكس بدوره على ألى أداءهم الأكاديمي.

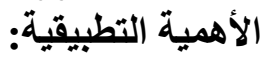


ل ستسهم نتائج هذه الدر اسة القائمين على شؤون الطلاب بشكل أفضل على توفير الخدمات

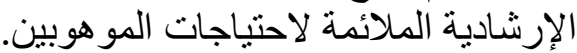

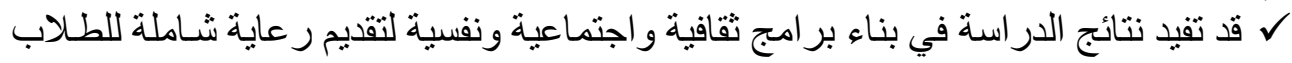
المو هوبين.

ل قد تفيد نتـائج هذه الدر اسـة المسؤولين عن الطلاب الموهوبين في تسـيل كافة الخدمات المقدمة.

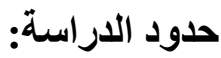

ـ الحدود الموضـوعية: اقتصـرت هذه الدر اسـة على التعـرف على الاحتياجـات الإرشـادية

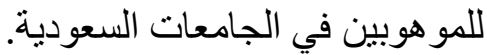

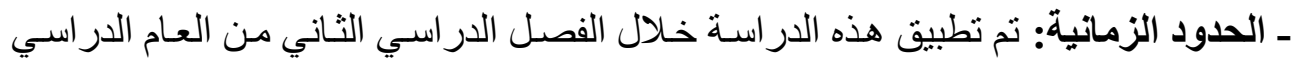

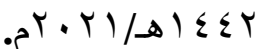
ـ ـ الحدود المكانية: تم تطبيق الدار استة في الجامعات السعودية. ـالحدود البشرية: اقتصرت هذه الدر اسة على الطلاب المو هوبين في الجامعات السعودية. مصطلحات الدراسة: الإدئة

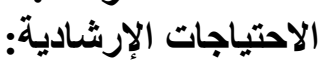

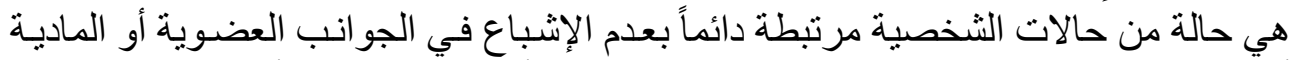

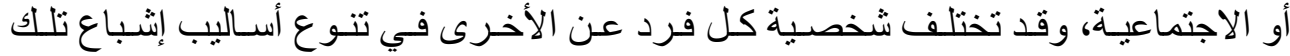

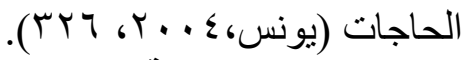

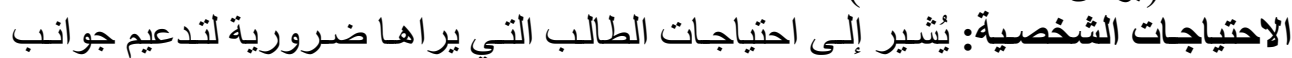
شخصيته و تحسين تو افقه العام. الاجئه

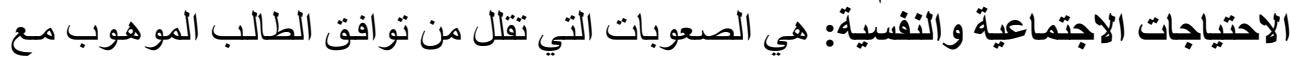

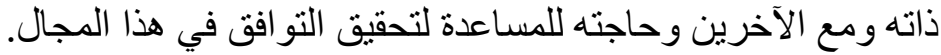

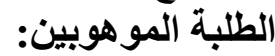

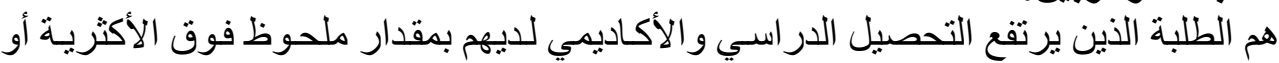

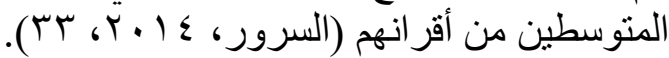

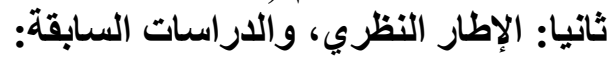
أولاً: الموهوبين: الإطرانين مفهوم الموهبة و الموهن:

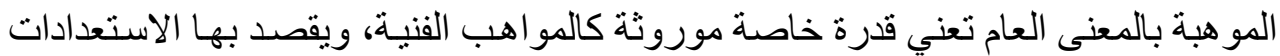

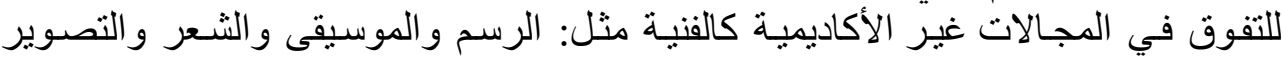

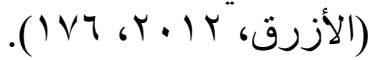




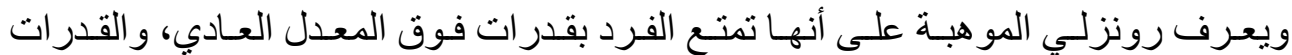

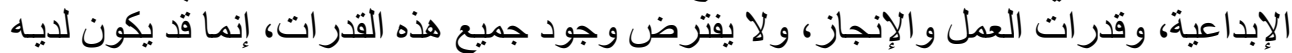

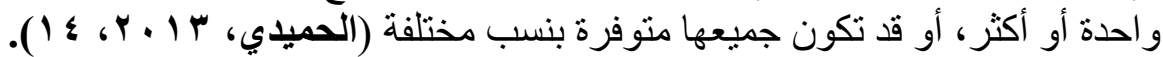

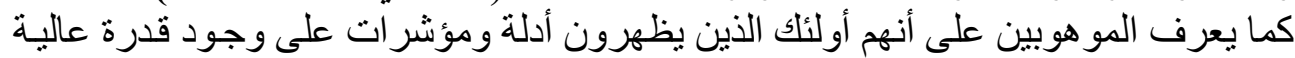

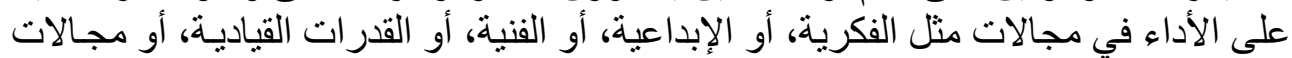

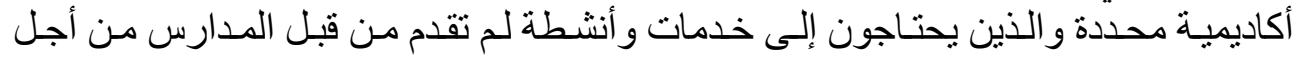

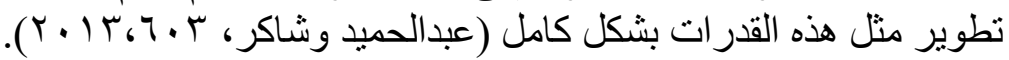

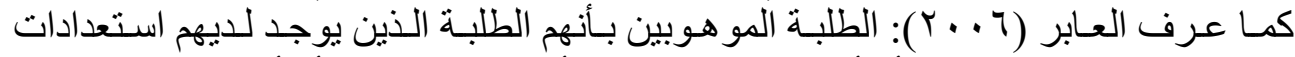

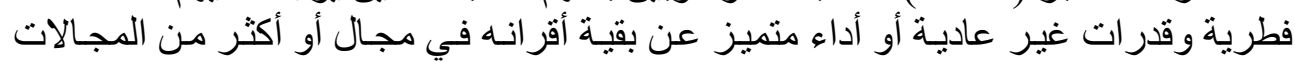

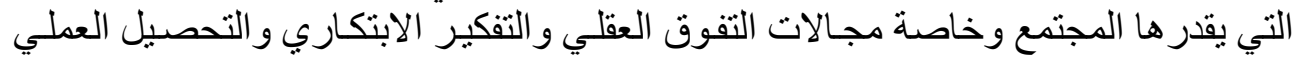
و المهار ات و القدر ات التهات الخاصة. خصائص الموهوبين

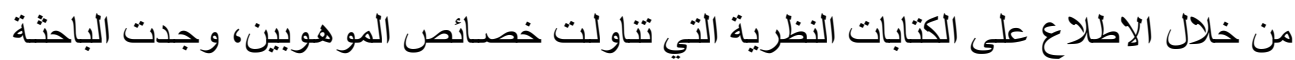

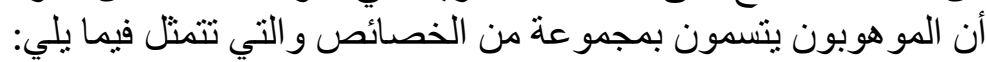

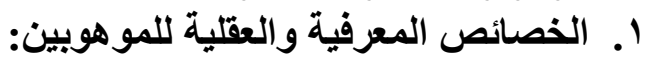

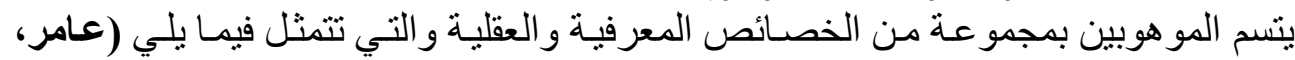

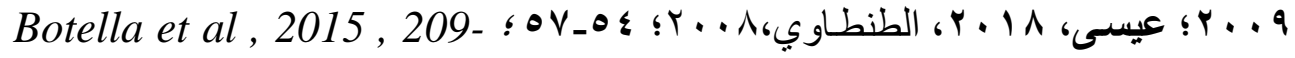

- - الثغف بالقر اءة و الاطلاع في سن مبكرة.

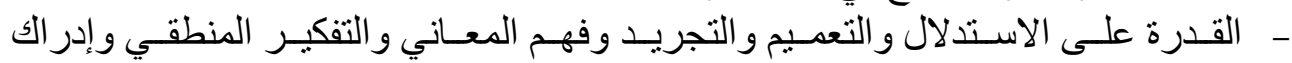
العلاقات.

- - إتقان و إنجاز الأعمال العقلية بدرجة يمكن وصفها بأنها خارقة.

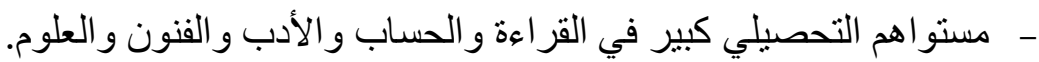
- قادر على التركيز و المثابرة و الانتباه و الملاحظة. - - محب للاستطلاع و الفضول ولن العقلي المنعكس على أسئلته المتعددة.

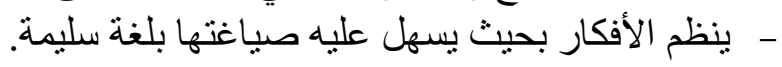

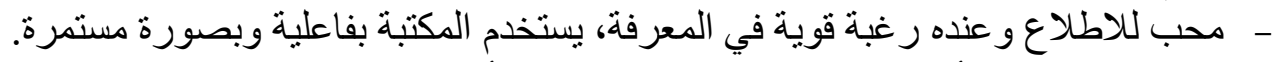

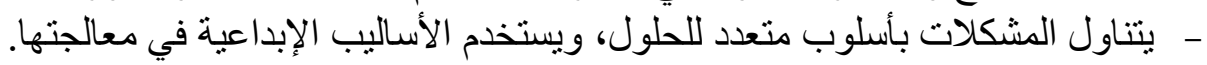

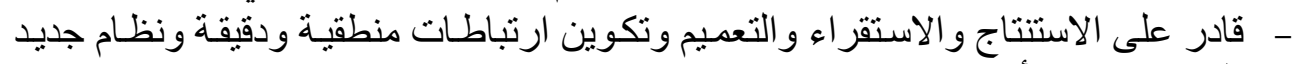
من العلاقات بين الأشياء. - قدرته على التعبير عن أفكاره الأصلية بسهولة ودقة وكيفية جيده. 
- ـيتفوق المو هـوب بالطلاقـة و المرونـة و الأصـالة و غز ارة التفكير و الحساسية للمشكلات

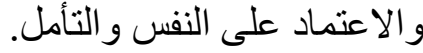
- يتصف المو هوبون بتنوع الهنمادماتهم و هو اياتهم وكثرتها.

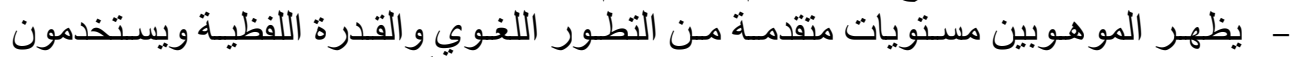

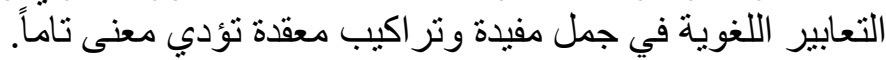

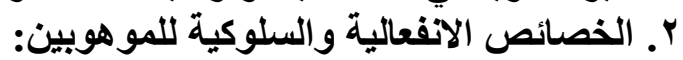

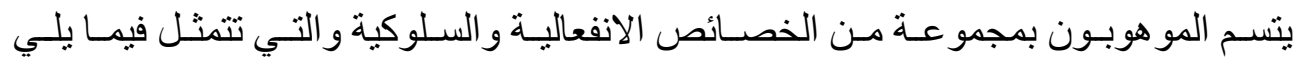

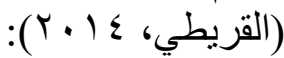
- حساسون انفعاليًا بشكل مفرط، ويتسمون بقوة المشاعر و الانفعالات إزاء ما يدور حولهم. - - - - يشعرون بالمخاوف مبكرًا.

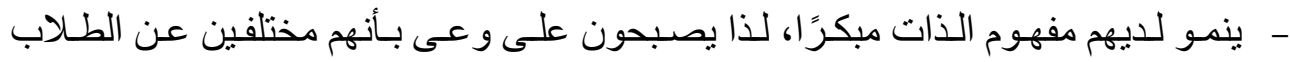

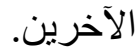
- لالديهم ثقة عالية بالنفس فيمـا يخص جانب مو هبتهم، وقد يكون لديهم ثقة أقل فيما يتعلق

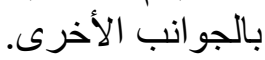
- قد يصبحون أكثر حساسية نحو النقا.

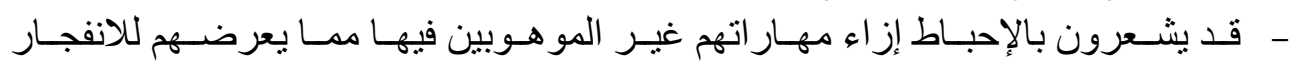
الانفعالي. - يقبلون المسئوليات التي يكلف بها عادة الأشخاص الأكبر منهم سنًا.

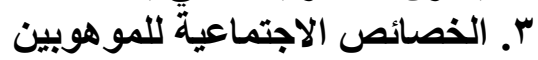

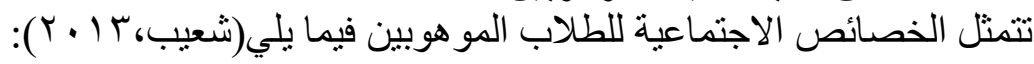

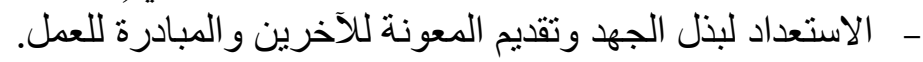
- الإقبال على الأنشطة الاجتماعية و الثنقافية.

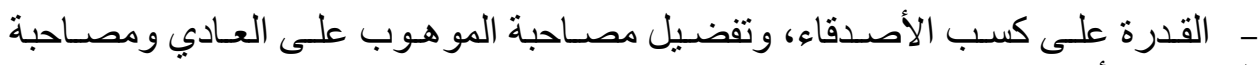

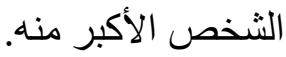
- الاعتز از و التقة بالنفس وحب النبه النبطرة و الاستقلالية.

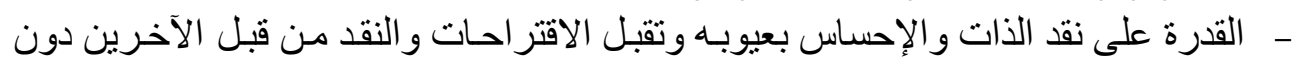

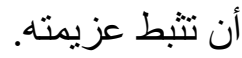
- تحمـل المسؤولية والقدرة على قيـادة الآخرين، ووجود الرغبـة القويـة في التفوق على الآخرين. - تفضيل الألعاب المعقدة والأنشطة التي تحتاج إلى التحدّي وأعمال التفكير. 
- - المبادرة في اقتر اح حلول للمو اقف المشكلة، وقد يتسم سلوكه أحيانـا بالتحدي و عدم الخضوع للأو امر. ع. حاجات الطلاب الموهوبين:

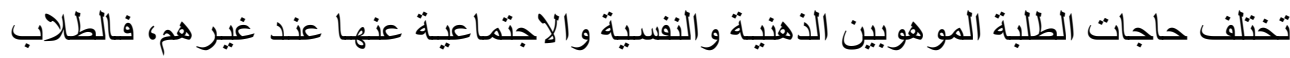

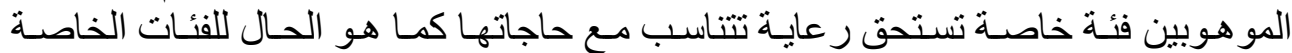

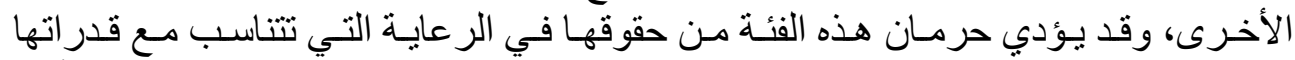

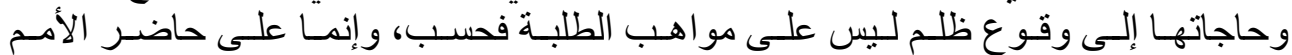

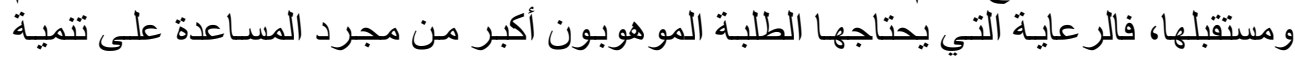

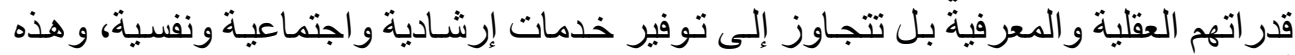

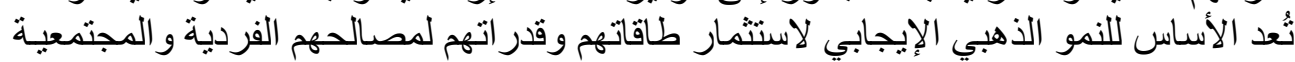

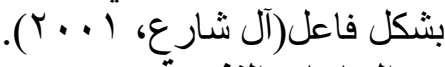
•. الحاجات النفسية:

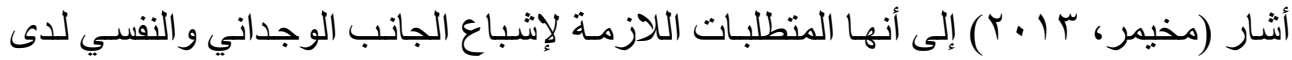

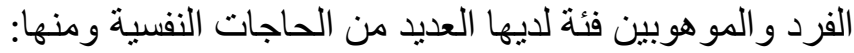

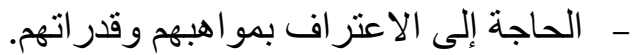

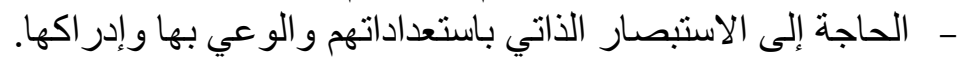

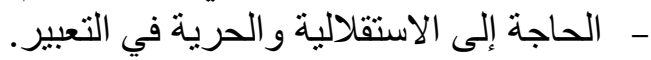

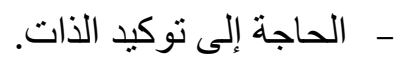
- - الحاجة إلى الفهم المبني على التعاطف الته والتقبل غير المشروط من الآخرين.

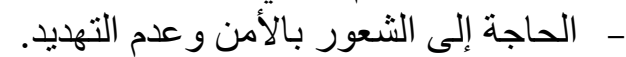

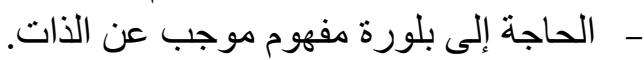
- - الحاجة إلى مزيد من الرئ بلى الرعاية المتخصصة.

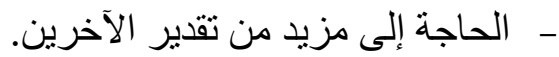

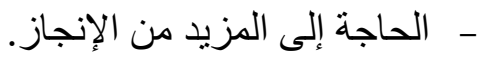

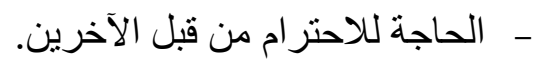

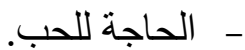
و. الحاجات الاجتماعية:

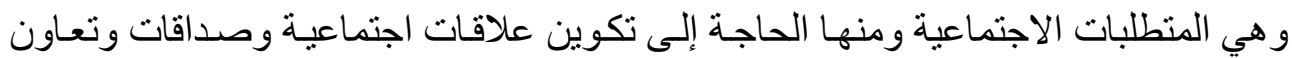

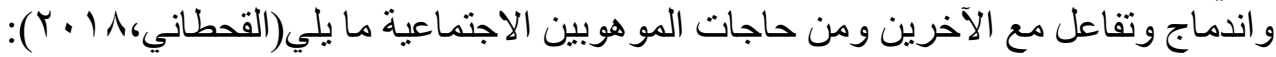

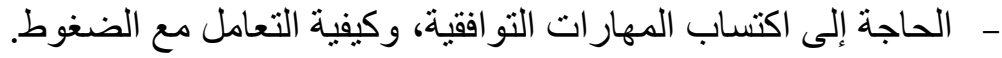

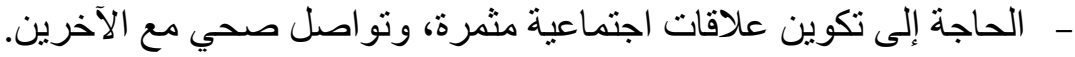

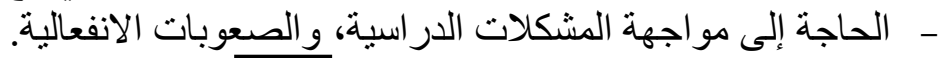




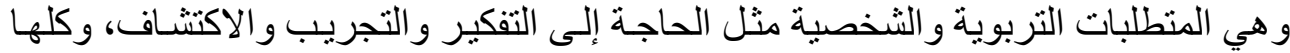

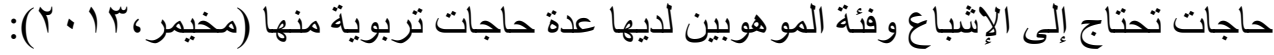

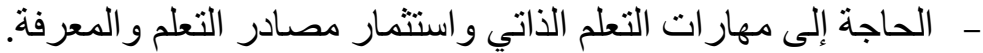

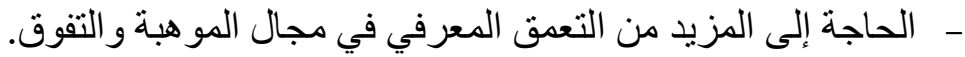

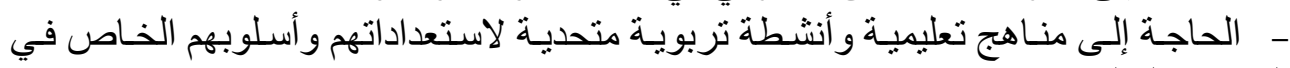
التفكير و التعلم. التها

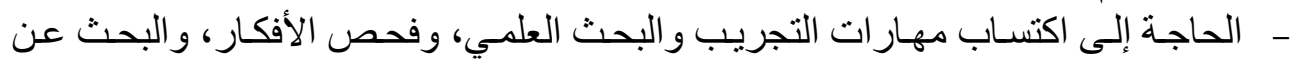
الحلول واقتر اح الفروض اكت واختبار ها في عالم الو اقع ومناقثنة النتائج.

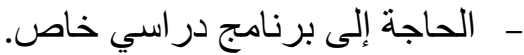

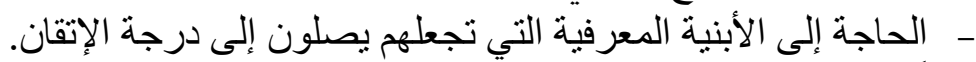
ثانياً: النظريات التي التناولت مفهوم الحاجات:

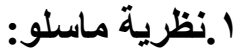

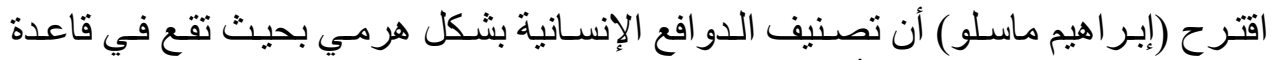

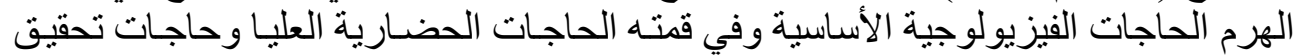

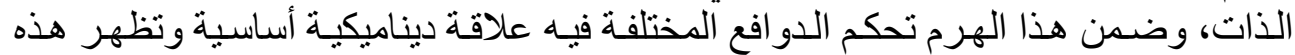

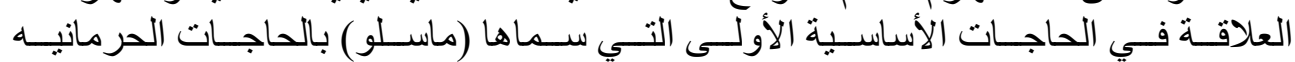

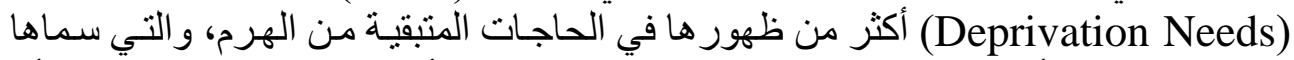

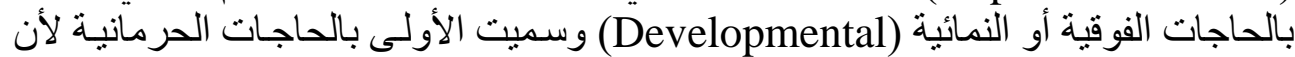

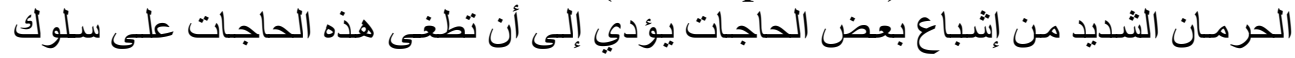

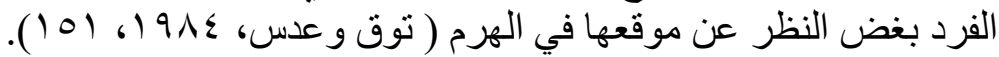

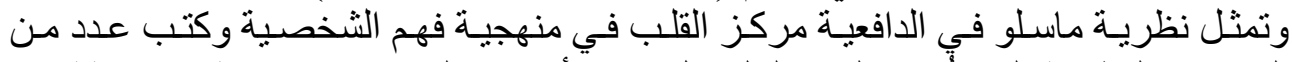

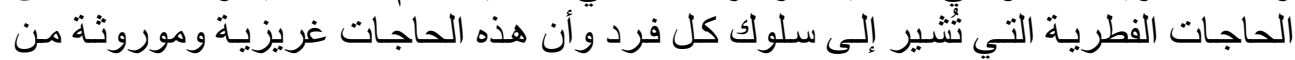

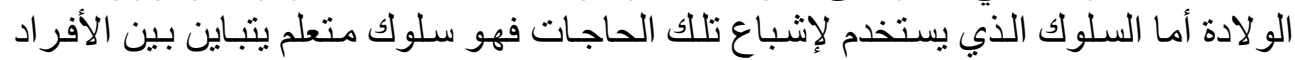

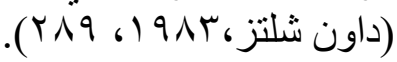

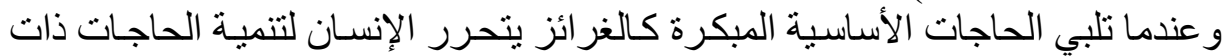

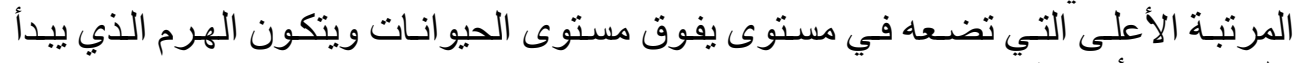

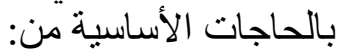
- الحاجـات الفسـيولوجية physiological needs: مثـل الطعـام و الجـنس والثــراب و الراحة. - حاجة الأمن (security needs): تتمثل بالحاجة إلى الوقاية والابتعاد عن المخاطر. 
- الحاجة إلى الحب و الاتنماء :love and belonging needs: مثل الحاجة إلى العلاقة مع الناس والحاجة إلى الانتماء للجماعة. - كالحاجة إلى تقدير الذات Esteem Needs: مثل الحاجة إلى الثقة بالنفس وشعور الفرد

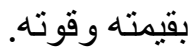

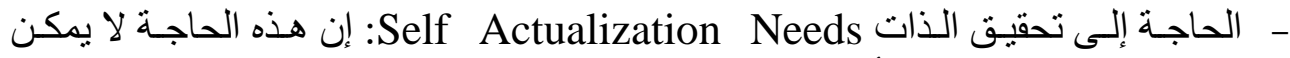
الوصول إليها إلا حينما تثبع أو يتم إنباع الحاجات التي دونها في هرم الحاجات (المعيني، لإنيكن

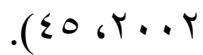

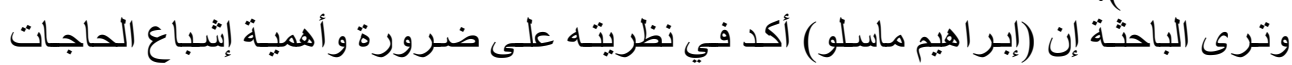

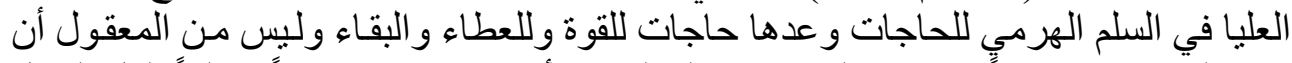

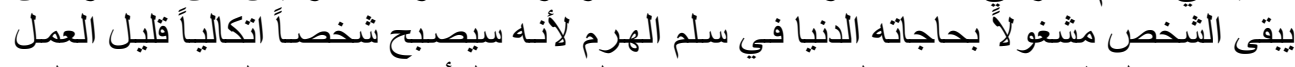

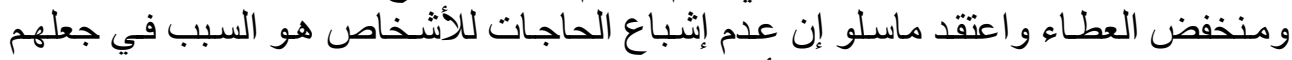

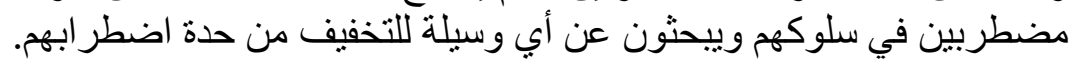

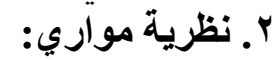
يصنف مـواري الحاجـات الإنسـانية لـى الفرد طبقاً لطريقة التعبير عنها في السلوك إلىى

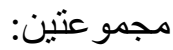
أ. الحاجات الظاهرة: وهي الحاجات التي تعبر عن نفسها أو يسمح لها بالتعبير عن نفسها

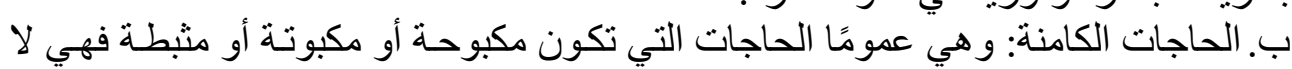

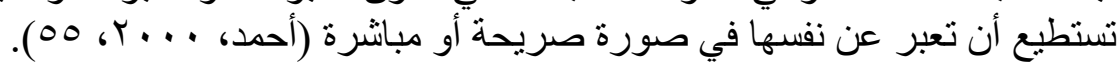

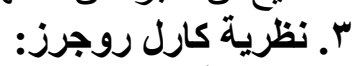

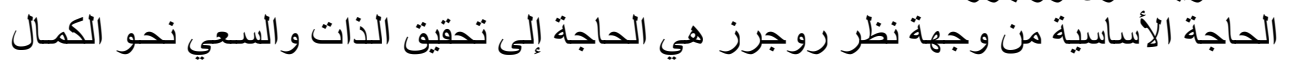

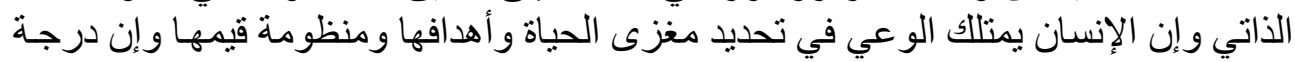

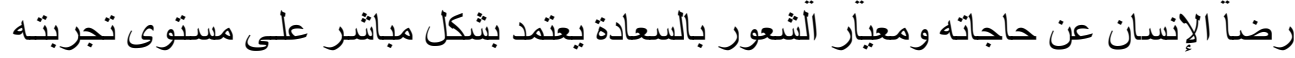

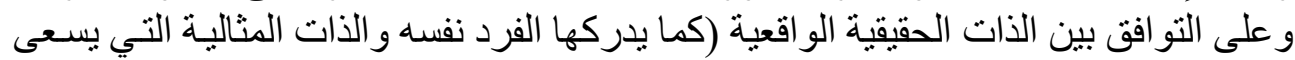
ويطمح للوصول إليها).

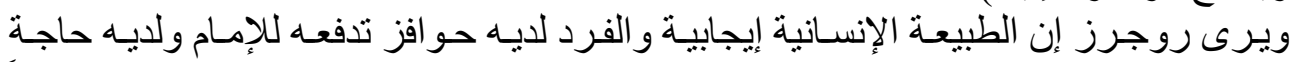

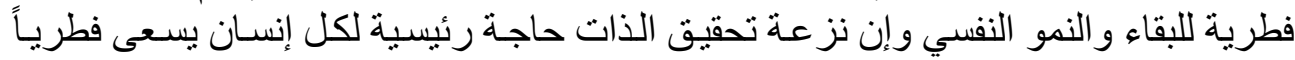

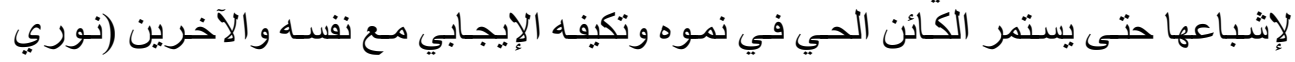

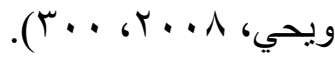


ثالثاً: الإرشاد النفسي للموهوبين: مفهوم الإرشاد النفسي للمو هوبين:

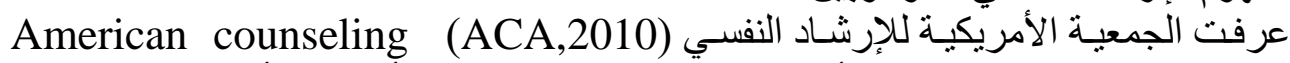

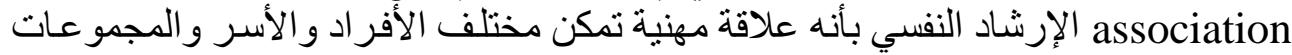

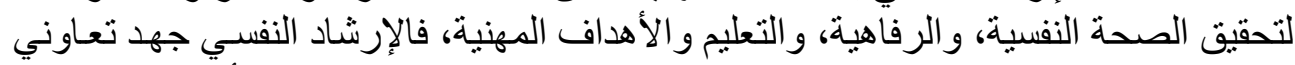

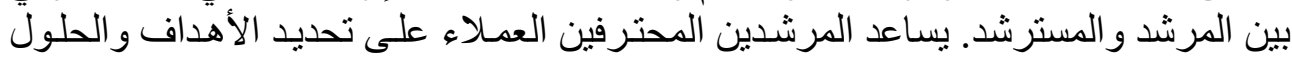

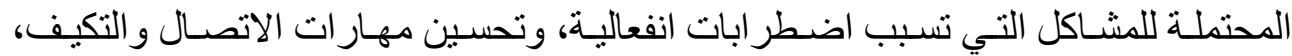

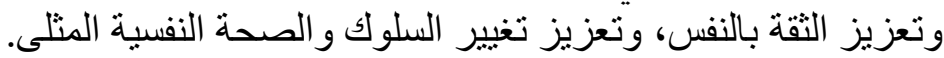
خصائص الإرشاد النفسي للمو هوبين:

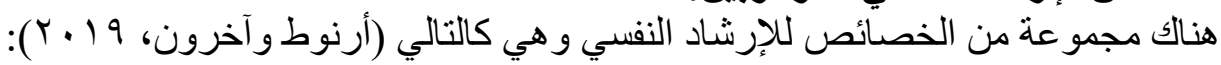

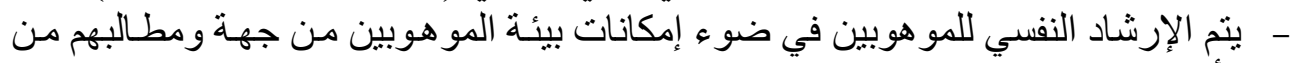

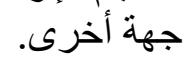

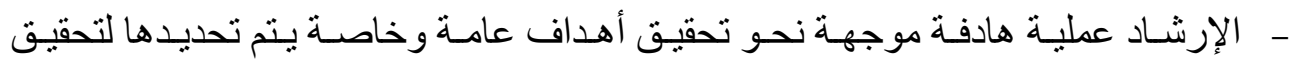

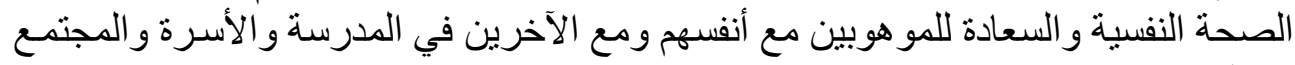
عامة.

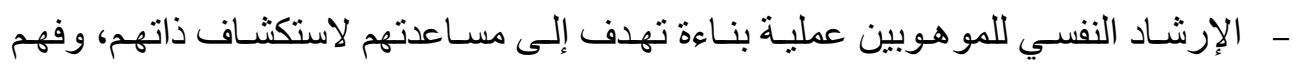

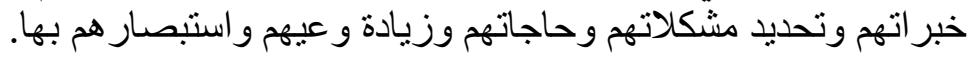

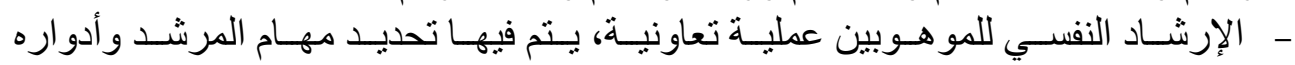

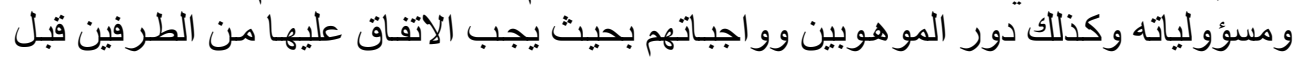
البدء في العمل الإرشادي.

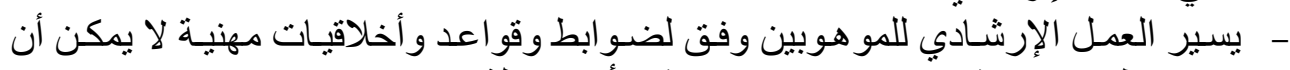

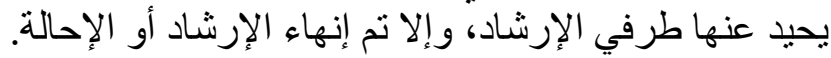

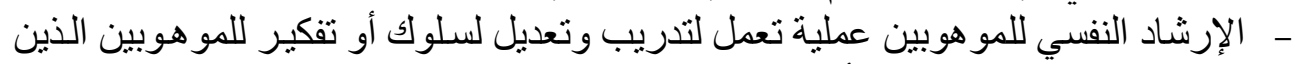

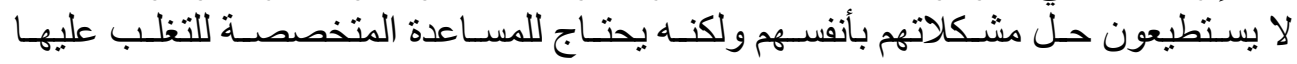
ومواجنها.

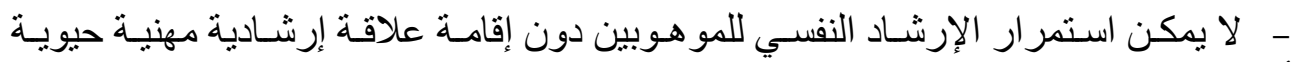

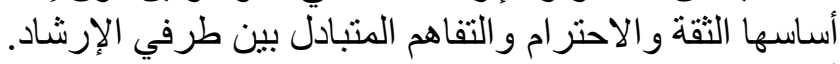
أهداف الإرشاد النفسي للمو هوبين:

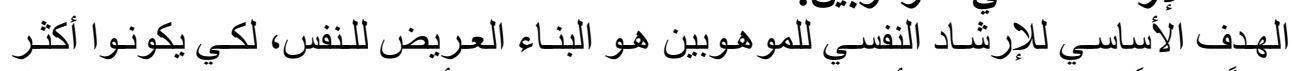

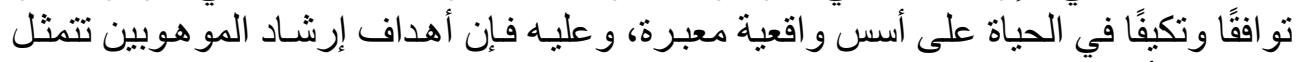

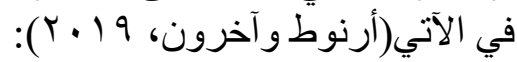
- تحقيق الصحة النفسية للمو هو بين. 
- تزوويد المو هوبين بـالو عي و المعرفة و المهار ات التي تمكنهم من التغلب على مشكلاتهم الاجتماعية و الثخصية.

- التمكين النفسي و المجتمعي للمو هوبين كفئة لها سمات وحاجات خاصة.

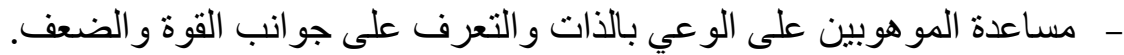

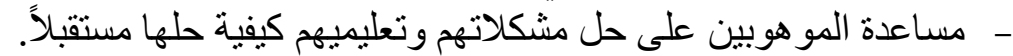

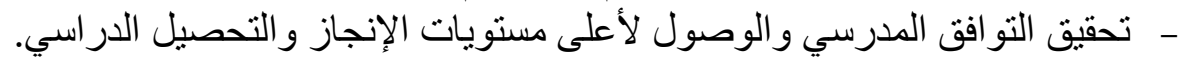

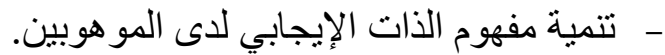

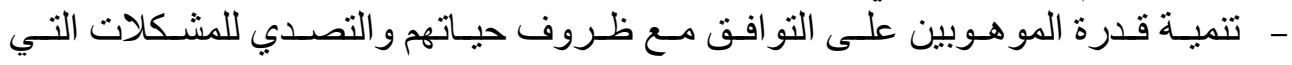
تو اج8هم. - استبصار المو هوبين بخصائصهم وقدر اتهم التي يتميزون بها عن الآخرين.

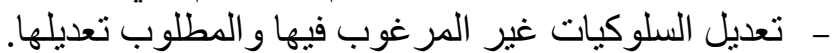
- - النمو الثخصي و المهني واستغلال قدر اتهم المعرفية الفائقة و إمكاناتهم الاستغلال الأمثل. - تنمية مهار ات القرن الحادي و العشرين للمو هو بين.

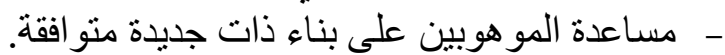

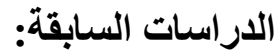

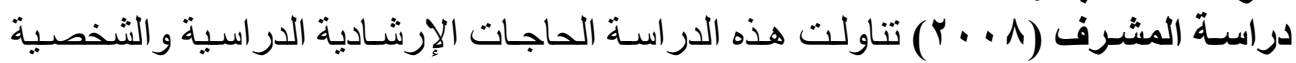

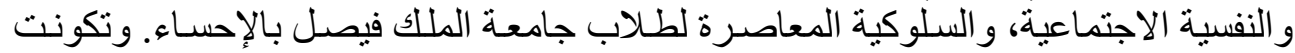

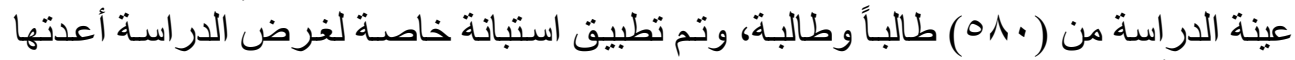

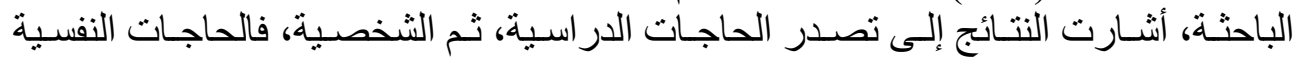

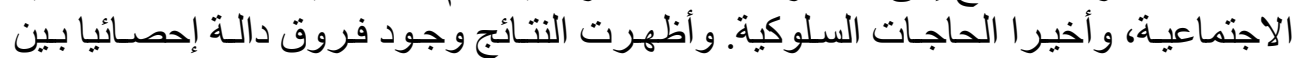

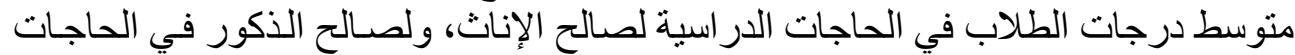

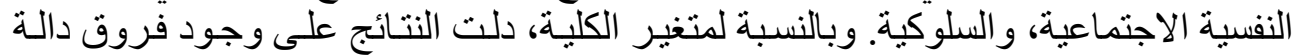

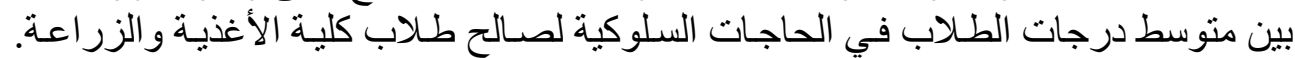

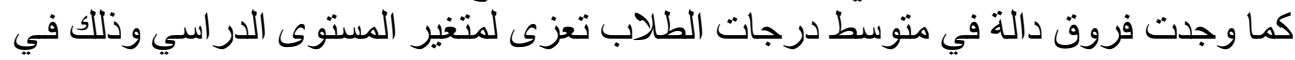

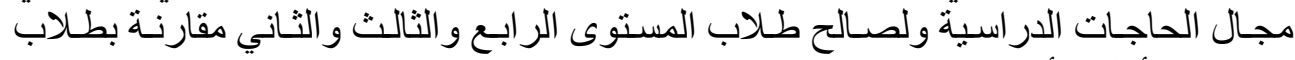

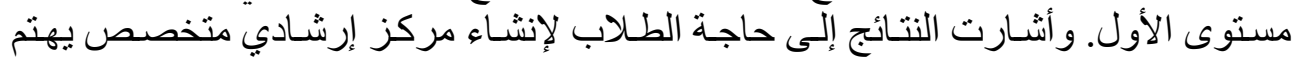

دراسة كاسيكي (kesici,2008) في تركيا حول الحاجـات الإرشـادية والتوجيه لدى الطلبة

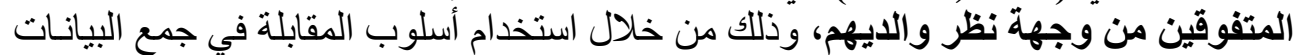

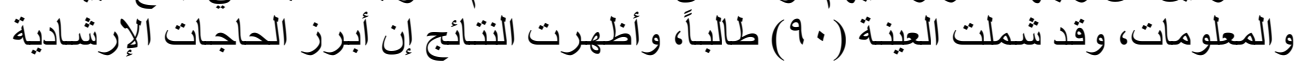

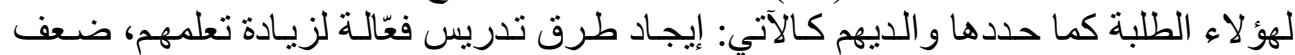

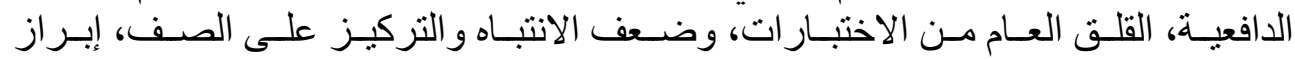


اهتماماتهم المهنية، ضعف المعلومات عن المهنة في المستقبل، تطوير المهار ات الاجتماعية

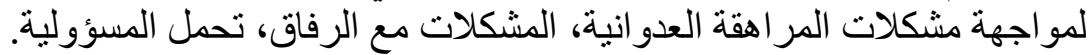

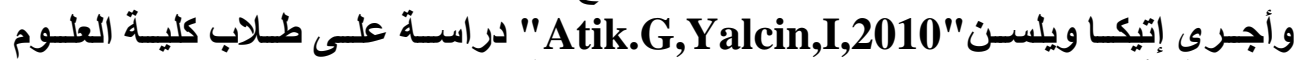

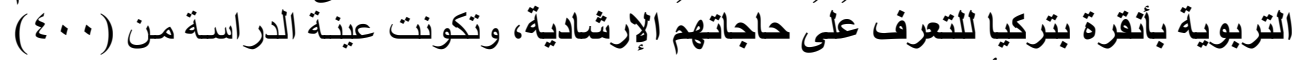

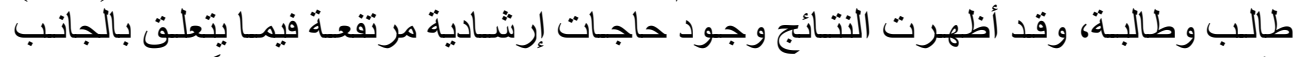

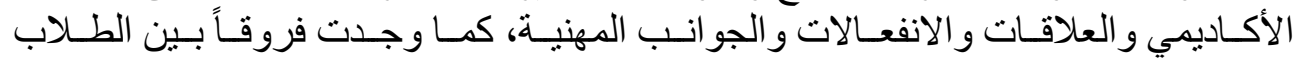

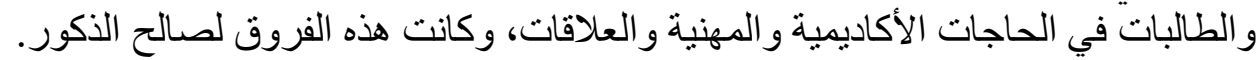

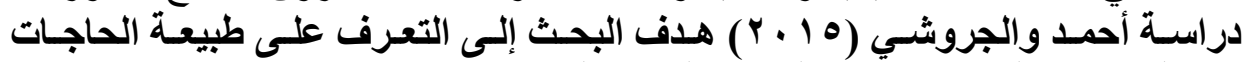

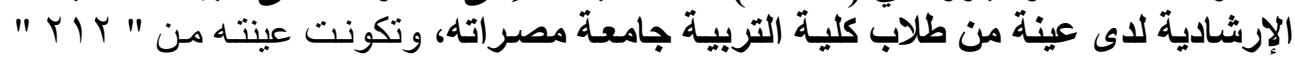

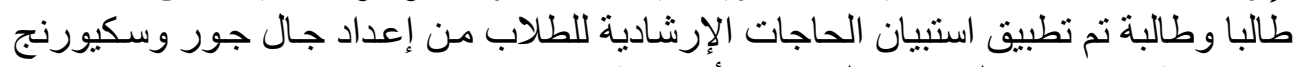

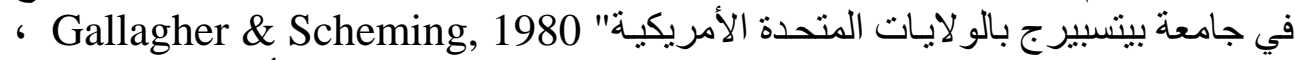

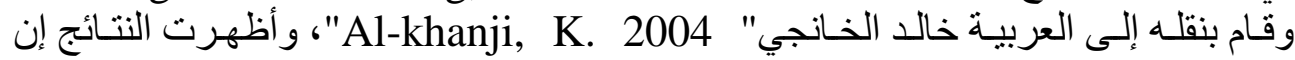

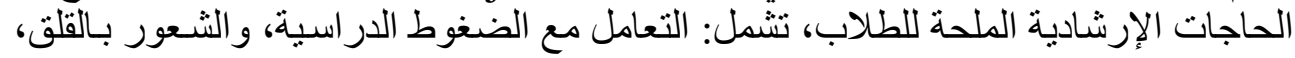

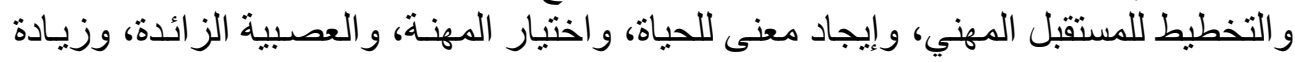

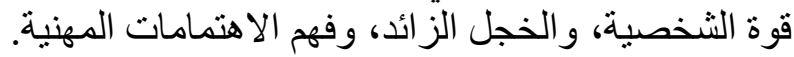

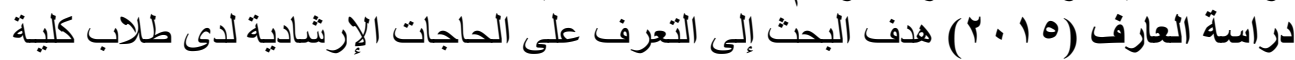

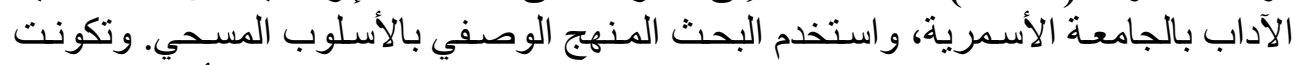

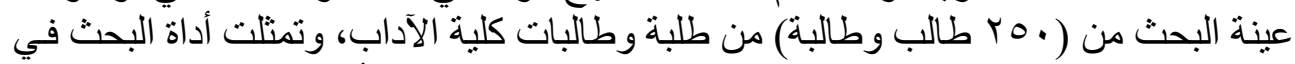

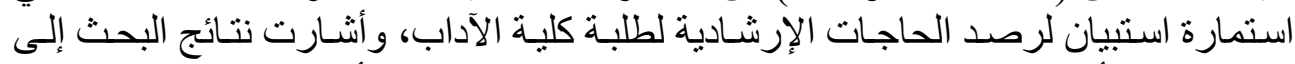

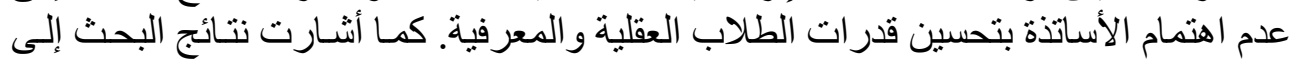

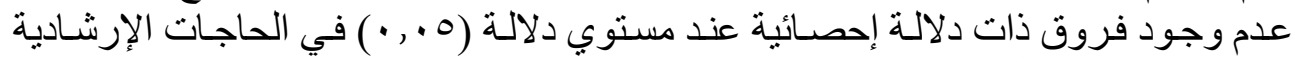
لاى الطلاب تعزى لمتغير الجنس.

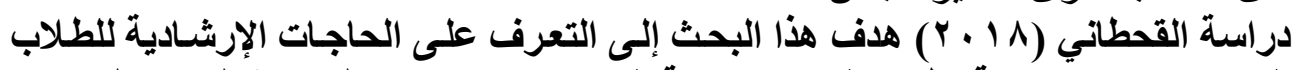

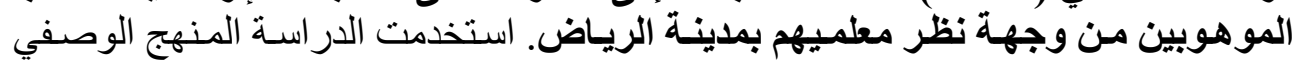

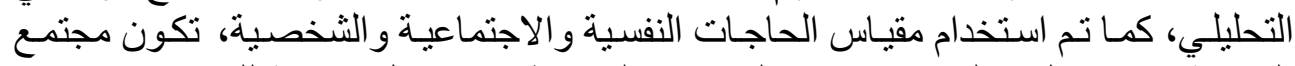

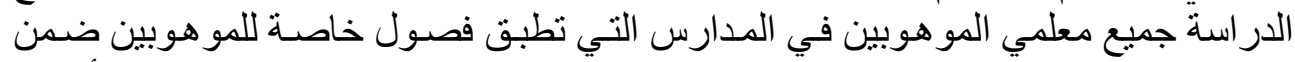

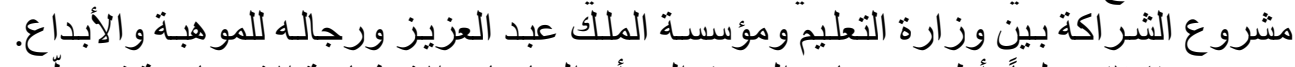

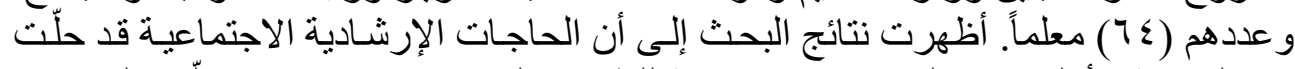

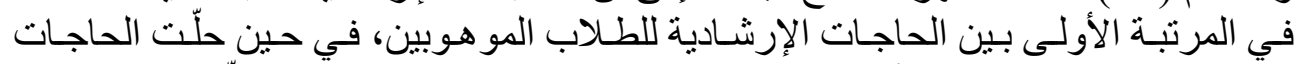

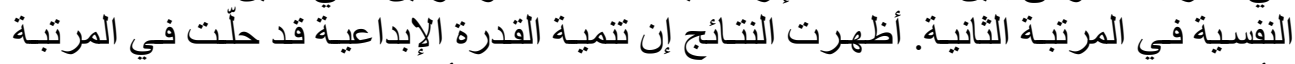

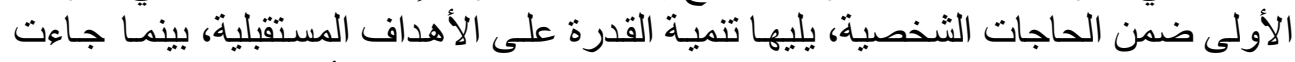

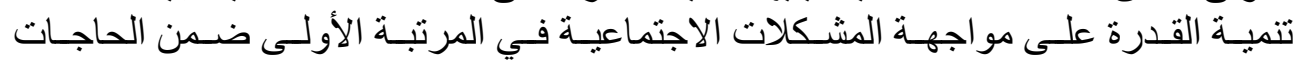




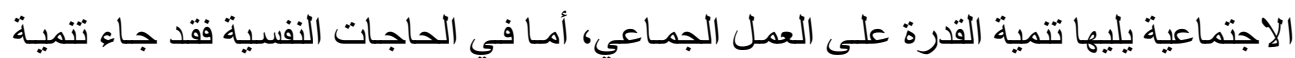

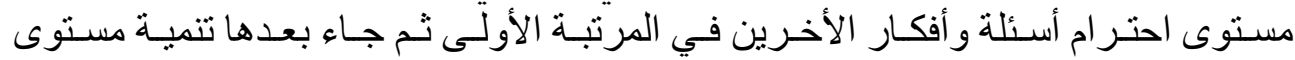

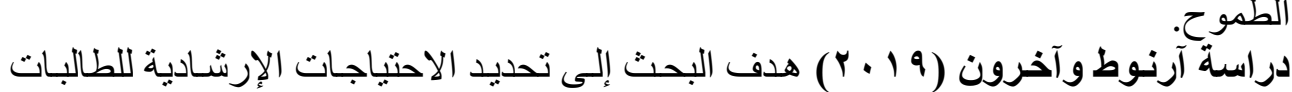

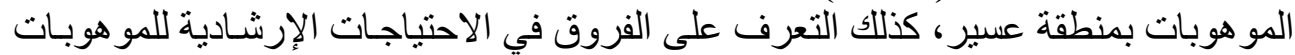

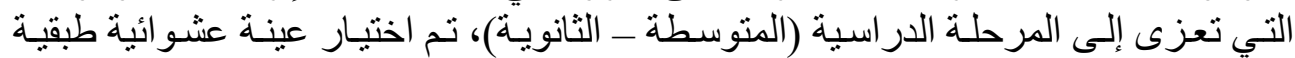

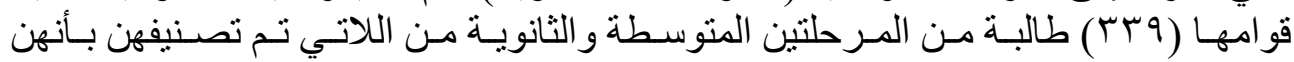

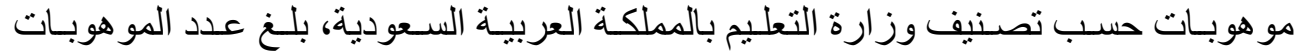

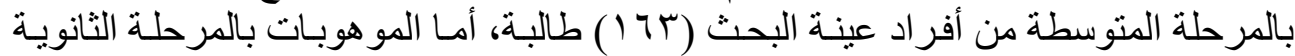

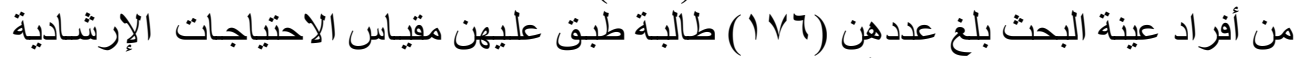

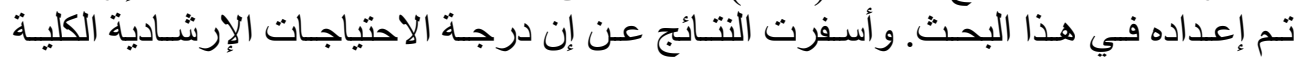

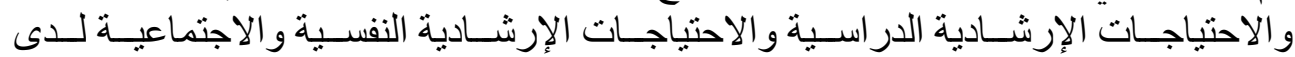

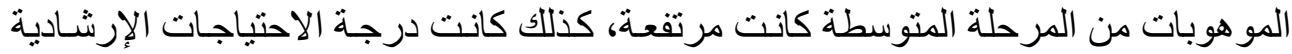

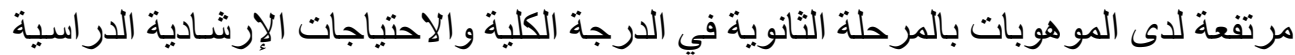

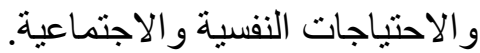
التعقيب على الاراسات السابقة: الإنة

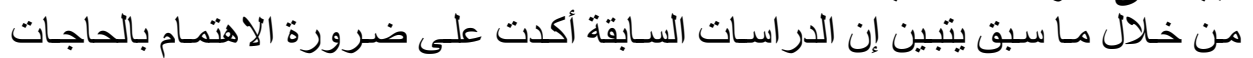

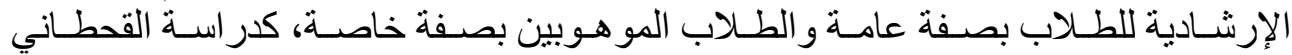

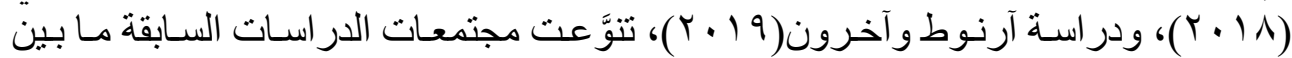

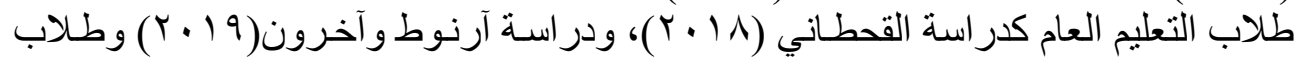

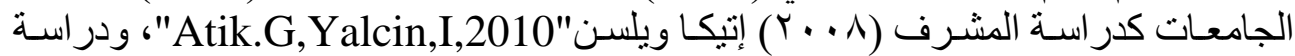

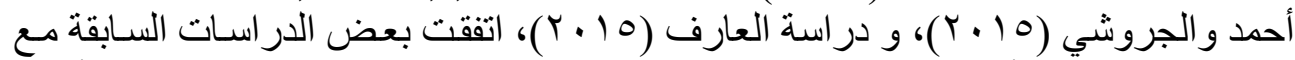

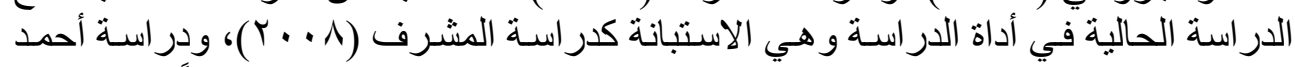

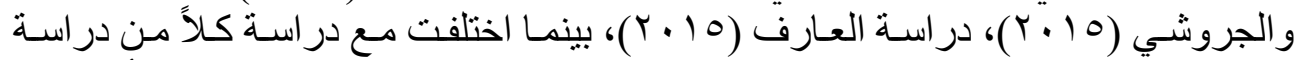

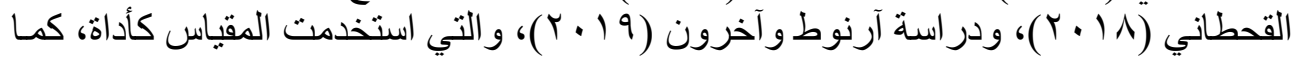

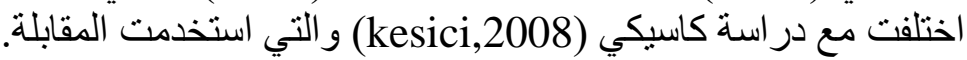

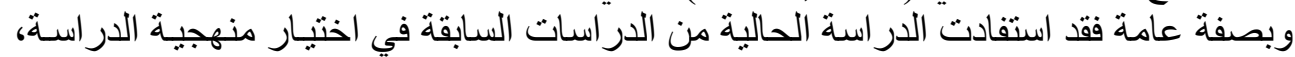

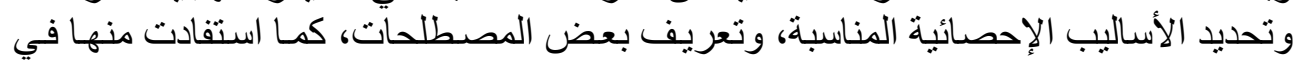

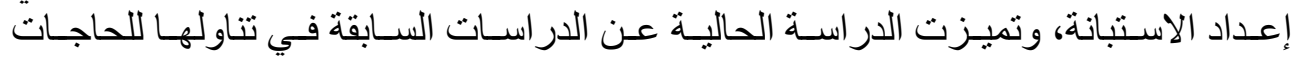
الإرشادية للطلاب المو هوبين في الجامعات الستولة السعودية. 


\section{الإجراءات المنهجية للاراسة:}

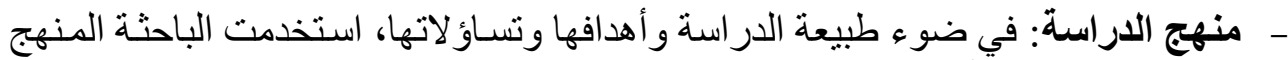

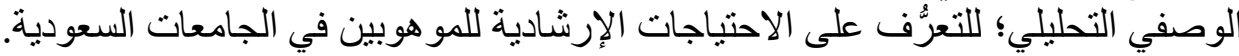

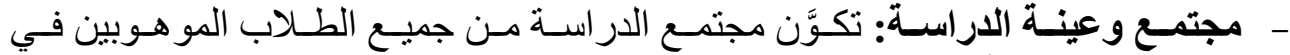

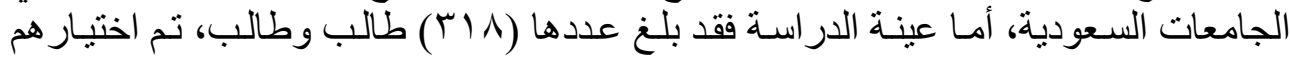

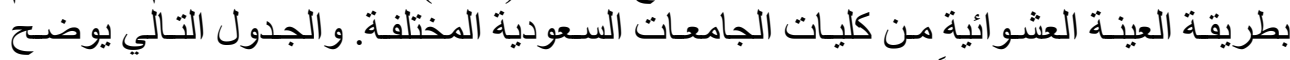

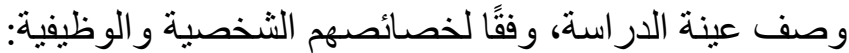
جدول (1): يوضح توزيع عينة الدر اسة وفقًا للبيانات الأولية.

\begin{tabular}{|c|c|c|c|}
\hline النسبة & التكرار & & \multirow{4}{*}{ الجنس } \\
\hline $0 \leqslant, V$ & $1 V \varepsilon$ & ذكر & \\
\hline$\varepsilon 0, r$ & $1 \leq \varepsilon$ & أنتى & \\
\hline$\% 1 \ldots$ & 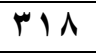 & المجموع & \\
\hline$\wedge \varepsilon, \Gamma$ & Yฯ^ & كليات علمية & \multirow{3}{*}{ الكلية } \\
\hline $10, V$ & 0. & كليات أدبية & \\
\hline$\% 1 \ldots$ & $\mu / \Lambda$ & المجموع & \\
\hline$r, 1$ & 1. & المستوى الثاني & \multirow{8}{*}{ الأكاديمي } \\
\hline $1 \Lambda, Y$ & 01 & المستوى الثالث: & \\
\hline$r v, V$ & $\pi$. & المستوى الر ابع & \\
\hline$Y_{1, \varepsilon}$ & 71 & المستوى الخامس & \\
\hline $9, \varepsilon$ & $r$ & المستوى السادس & \\
\hline $7, r$ & $r$. & المستوى السابع & \\
\hline$r, \Lambda$ & IT & ماجستير & \\
\hline$\% 1 \ldots$ & $M / \Lambda$ & المجموع & \\
\hline
\end{tabular}

-

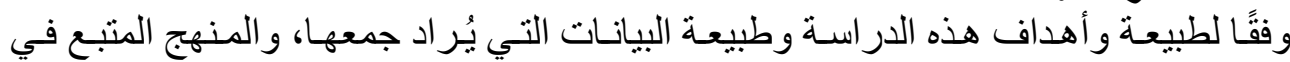

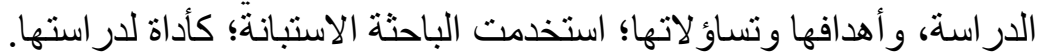

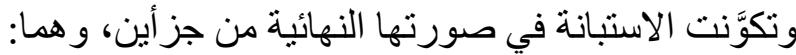

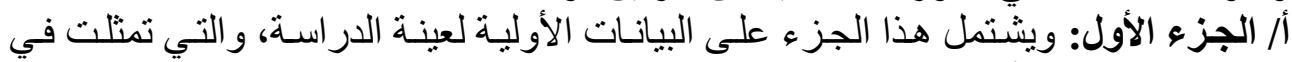
(الكلية، المستوى الأكاديمي، الجنس).

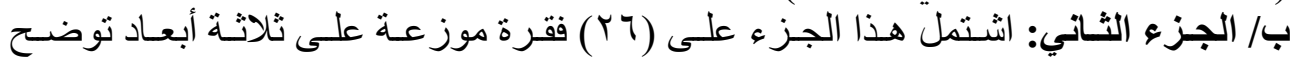

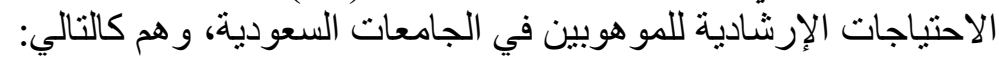

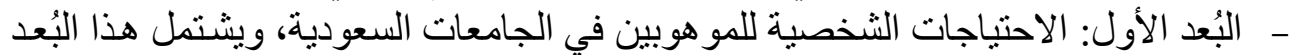
على (V) فقر ات الات. 
- ـ البُعد الثاني: الاحتياجـات الاجتماعية للمو هوبين في الجامعات السعودية، ويشتمل هذا

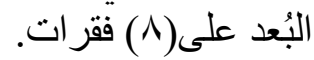
- البُعد الثالث: الاحتياجات النفسية للمو هوبين في الجامعات السعودية، ويشتمل هذا البُعد

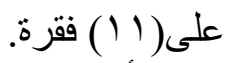

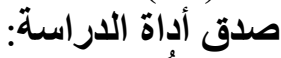

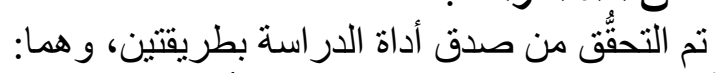
أ / الصدق الظاهري (الخارجي) للأداة:

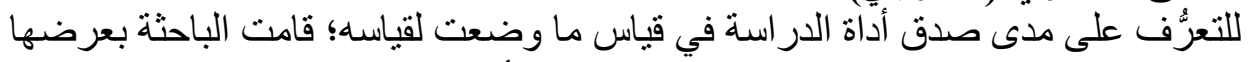

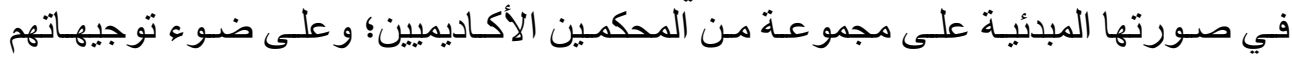
ومقترحاتهم؛ نوصلت الباحثة للاستبانة بصورتها هنا النهائية.

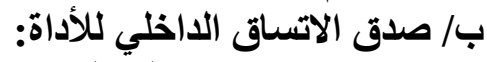

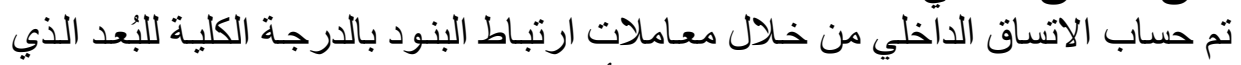

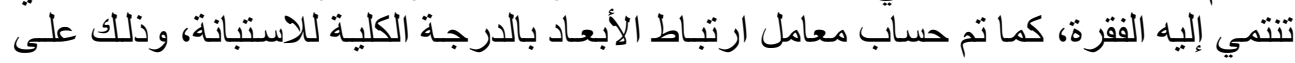

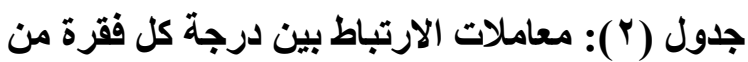

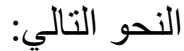

فقرات الاستباتة بالارجة الكلية للبعد الأي تنتمي إليه الفقرة

\begin{tabular}{|c|c|c|c|c|c|}
\hline \multicolumn{2}{|c|}{ الاحتياجات النفسية } & \multicolumn{2}{|c|}{ الاحتياجات الاجتماعية } & \multicolumn{2}{|c|}{ الاحتياجات الشخصية } \\
\hline معامل الارتباط & العبارة & معامل الارتباط & العبارة & معامل الارتباط & العبارة \\
\hline **, , VMY & 17 & $* *, \wedge \circ \leqslant$ & $\Lambda$ & $* *, \varepsilon, r$ & 1 \\
\hline$* *, \wedge \cdot 9$ & IV & $* *, \wedge 9 \vee$ & 9 & $* *,, 7 \leq 1$ & r \\
\hline$* *, \wedge, \uparrow$ & 11 & $* *, \wedge r q$ & 1 . & $* *, 9$. & $r$ \\
\hline$* *, \wedge \leqslant \Gamma$ & 19 & $* *, \wedge \vee \wedge$ & 11 & $* *, 0 \leq 9$ & $\varepsilon$ \\
\hline$* *, \wedge \wedge 1$ & $r$. & $* *, \wedge \wedge \neg$ & IT & $* *,, \vee\urcorner \leq$ & 0 \\
\hline$* *, \wedge \circ \leq$ & YI & $* *, 1,01$ & $1 \pi$ & $* *,, \vee 90$ & 7 \\
\hline$* *, \wedge \circ \wedge$ & rt & **, , $\vee 9$ & $1 \varepsilon$ & **, , VTr & V \\
\hline$* *, 0 \leq 7$ & rr & $* *, 777$ & 10 & - & - \\
\hline$* *,, \vee \circ \wedge$ & $Y \leqslant$ & - & - & - & - \\
\hline$* *, \wedge \vee \mu$ & ro & - & - & - & - \\
\hline$* *, \wedge r I$ & ru & - & - & - & - \\
\hline
\end{tabular}

** دالة عند مستوى الدلالة ا • , • فأقل. 


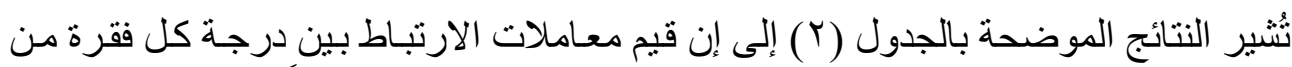

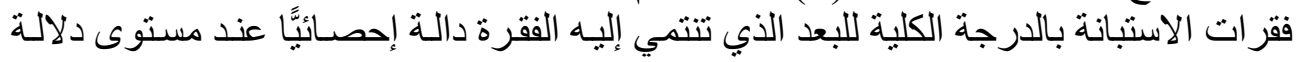

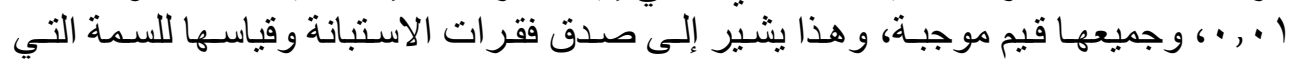

وضنت لقياسها.

جدول () معاملات الارتباط بين درجة كل بعد من أبعاد الاستبانة بالارجة الكلية للاستبانة

\begin{tabular}{|c|c|c|}
\hline معامل الارتباط & أبعاد الاستبانة & م \\
\hline$* *,, V \leq r$ & الاحتياجات الشخصية للمو هوبين. & 1 \\
\hline$* *, 9 \mu q$ & الاحتياجات الاجتماعية للمو هوبين. & r \\
\hline$* *, 910$ & الاحتياجات النفسية للمو هوبين. & $r$ \\
\hline
\end{tabular}

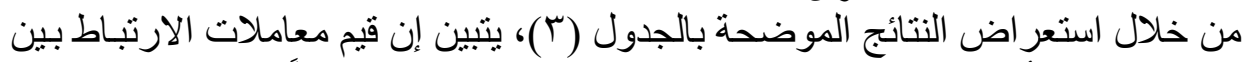

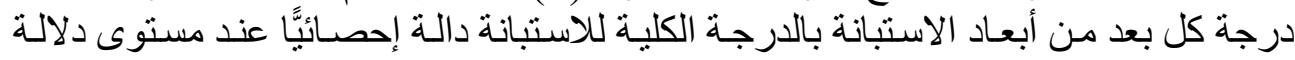

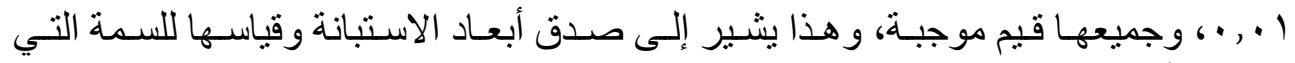

وضعت لقياسها.

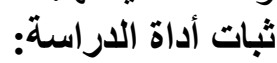

استـتخدمت الباحثـة (معادلـة ألفـا كرونبـاخ Cronbach'aAlpha)؛ للتأكد مـن ثبـات أداة

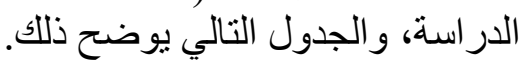

\begin{tabular}{|c|c|c|c|}
\hline معامل ثبات & الفقر اتد & \multicolumn{2}{|l|}{ أبعاد الدر اسـة } \\
\hline$\cdot, \vee \vee \backslash$ & V & الاحتياجات الشخصية للمو هوبين. & البعد الأول \\
\hline$\cdot, 9 M \mathrm{~V}$ & $\wedge$ & الاحتياجات الاجتماعية للمو هوبين. & البعد الثاني \\
\hline$\cdot, 9 \leqslant 1$ & 11 & الاحتياجات النفسية للمو هو بين. & البعد الثالث \\
\hline., 907 & rY & نجات العام لأداة الدر اسة & \\
\hline
\end{tabular}

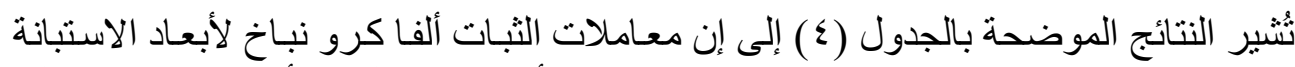

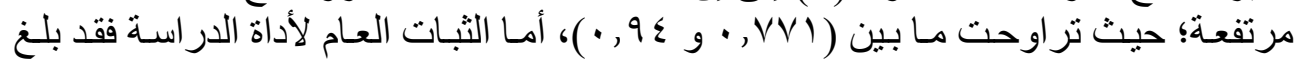

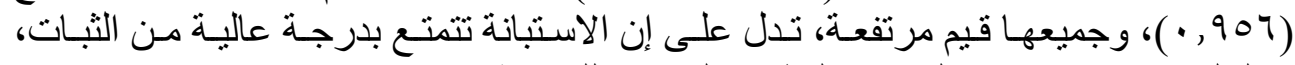

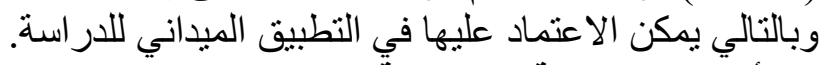

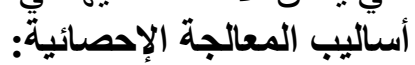

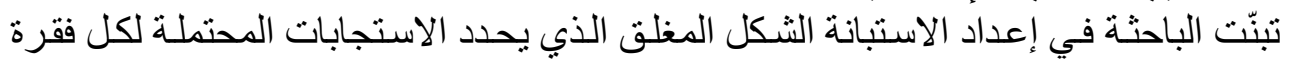

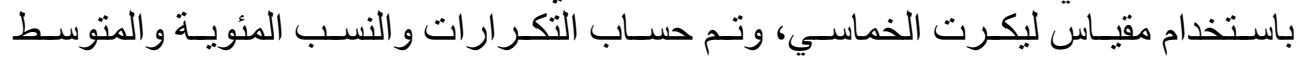




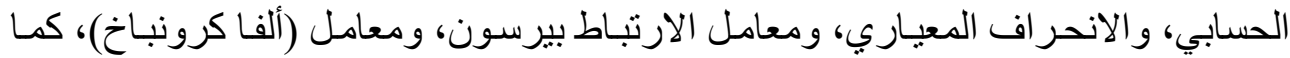

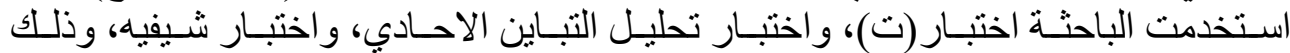

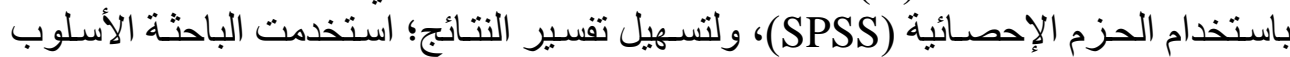

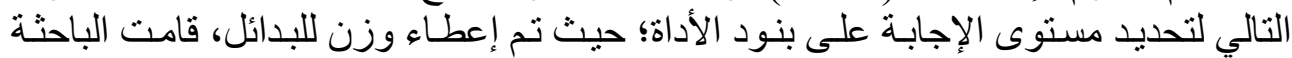

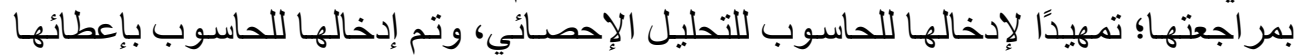

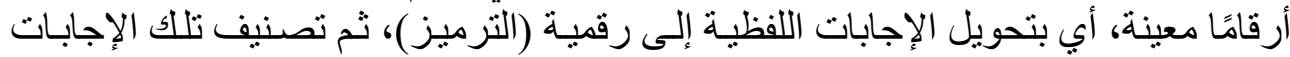

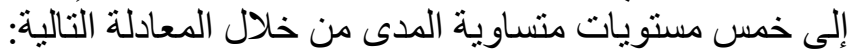

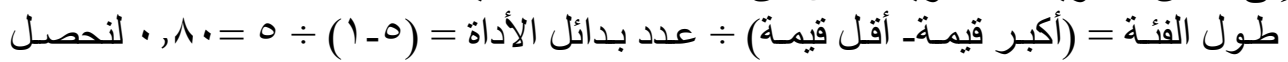
على التصنيف الذي يوضحه الجدول التيرة ألتالي: جدول (•) درجة الموافقة ومدى الموافقة

\begin{tabular}{|c|c|}
\hline مدى المتوسطات & الوصف \\
\hline $1-1, \lambda$. & بدرجة قليلة جداً \\
\hline $1, \lambda)-Y, T$. & بدرجة قليلة \\
\hline$r, T)-r, \varepsilon$. & بدرجة متوسطة \\
\hline$\Sigma, Y \cdot-Y, \Sigma)$ & بدرجة كبيرة \\
\hline $0, \cdots-\varepsilon, r_{1}$ & بدرجة كبيرة جداً \\
\hline
\end{tabular}

تحليل ومناقشة نتائج الدراسة:

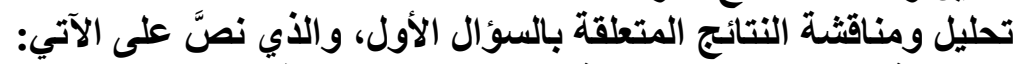

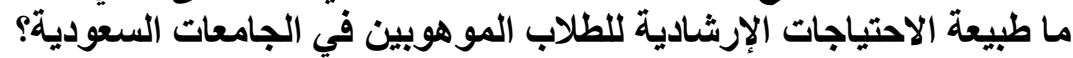

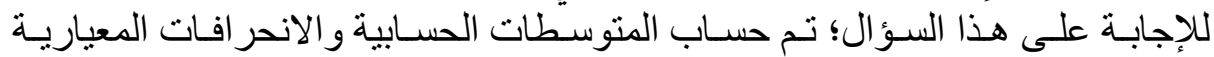

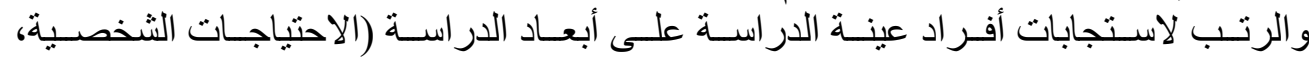

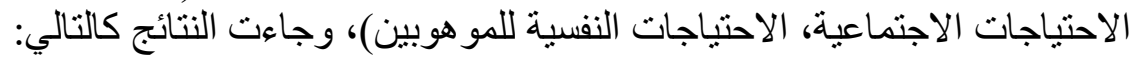

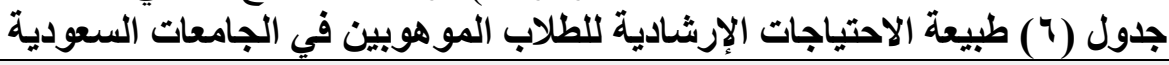

\begin{tabular}{|c|c|c|c|c|}
\hline درجة المو افقة & 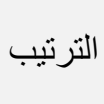 & الالنحيــــــــراف & الحسابي & أبعاد الدر اسة \\
\hline بدرجة كبيرة جداً & 1 & $\cdot, \Sigma V \mid$ & $\varepsilon, \pi Y$ & الاحتباجات الثخصية \\
\hline بدرجة كبيرة & $r$ & $\cdot, 9 \leq \wedge$ & $r, 9 q$ & الاحتياجات الاجتماعية \\
\hline بدرجة كبيرة جداً & r & $\cdot, \wedge \leqslant Y$ & $\varepsilon, \Gamma$. & الاحتياجات النفسية للمو هو بين \\
\hline بدرجة كبيرة جداً & & $\cdot$, iv. & $\varepsilon, \mu$ & الدرجة الكلية \\
\hline
\end{tabular}


من خلال استعر اض النتائج الموضحة بالجدول (T)، يتبين إن أفراد عينـة الدر اسـة مو افقون

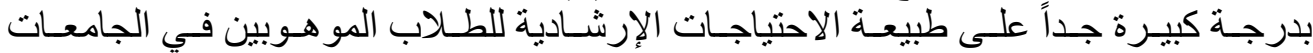

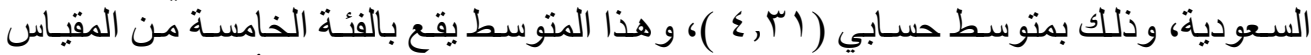

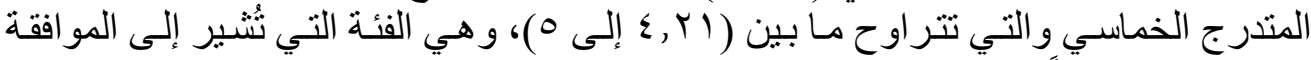

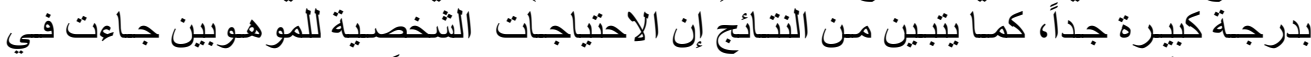

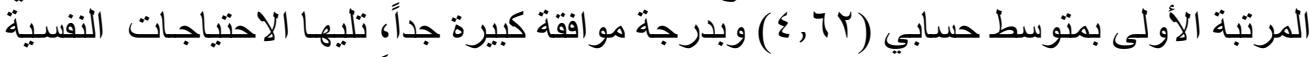

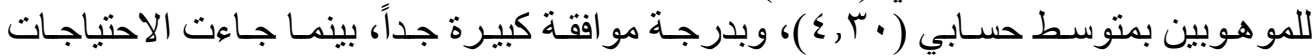

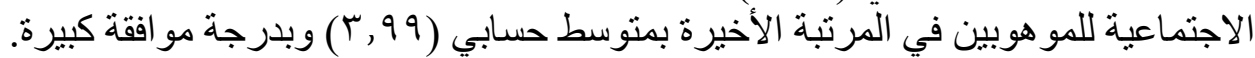

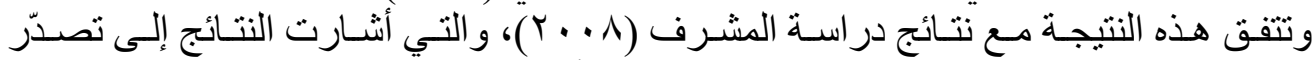

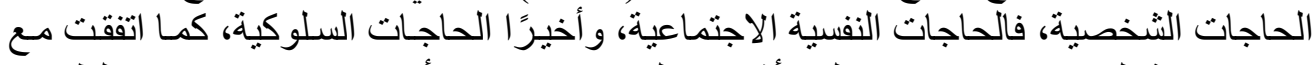

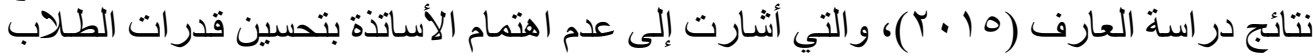
العقلية و المعرفية.

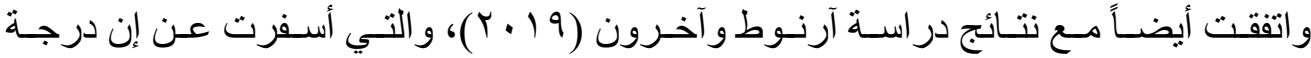

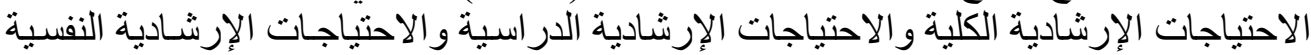

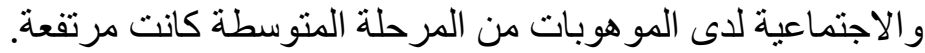

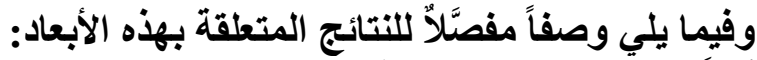

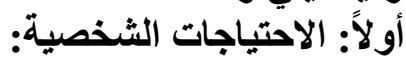

جدول (V) استجابات أفراد عينة الدراسة على الفقرات المتعلقة بالاحتياجات الثخصية

\begin{tabular}{|c|c|c|c|c|c|}
\hline المو افقة & الترتيب & 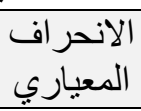 & الحسابي & 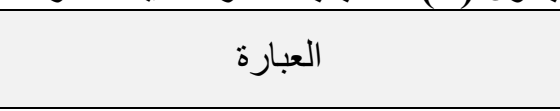 & r \\
\hline بدرجة كبيرة & 1 & $\cdot, r \circ 9$ & $\varepsilon, q$. & الحاجة لتنمية القدرة الإبداعية & 1 \\
\hline بدرجة كبيرة & $r$ & •, 077 & $\varepsilon, \vee q$ & الحستقة لنطوير و التخطيط له بشكل علمي سليم الثمولية في & r \\
\hline بدرجة كبيرة & $\varepsilon$ & $\cdot, 7 \cdot 1$ & $\varepsilon, \vee \wedge$ & الحاجة لتهيئة قيادات و اعدة في شتى & $r$ \\
\hline بدرجة كبيرة & r & • & $\varepsilon, \wedge \varepsilon$ & الحاجة لتنمية القدرة على التفكير الابتكاري & $\varepsilon$ \\
\hline بدرجة كبيرة & V & $1,1 \cdot r$ & $\varepsilon, Y$ & الحاجة لتتمية القدرة على إدارة حلقات & 0 \\
\hline
\end{tabular}




\section{مج (T) - ع (19) يناير r.r.PA}

\section{المجلة العربية لعلور الإعاقة والموهبة}

\begin{tabular}{|c|c|c|c|c|c|}
\hline المو افقة & الترتيب & الانحر اف المعياري & الحسابي & العبارة & r \\
\hline بدرجة كبيرة & 0 & - , 10 . & $\varepsilon, \varepsilon r$ & الحاجة لتطوير الثخصية لتكون قادرة على التى التحديف & 7 \\
\hline بدرجة كبيرة & 7 & $\cdot, \Lambda \vee Y$ & $\varepsilon, \leqslant 1$ & والحاجة للمسـاعدة و التطوير في فهم الذات التصّات الفحّال & V \\
\hline كبيرة جداً & بدر. & - , $\leqslant V I$ & $\varepsilon, 7 r$ & \multicolumn{2}{|l|}{ المتوسط الحسابي العام } \\
\hline
\end{tabular}

* المتوسط الحسابي من 0 درجات.

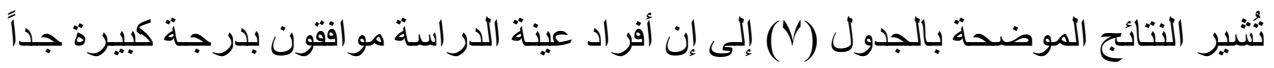

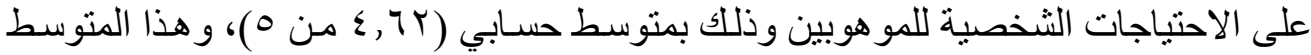

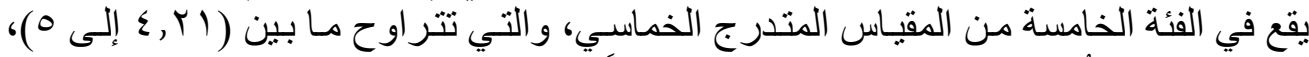

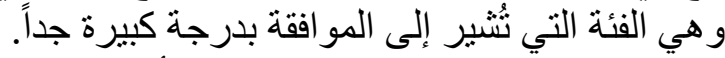

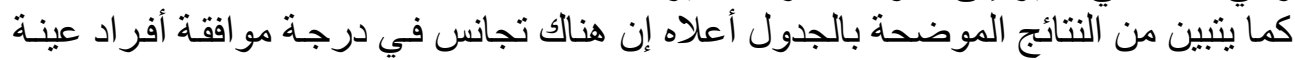

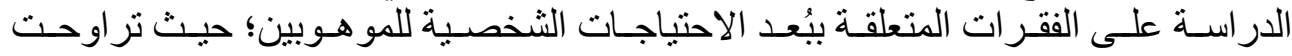

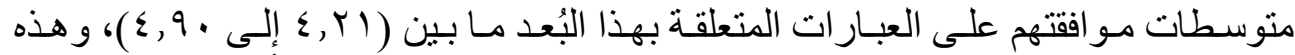

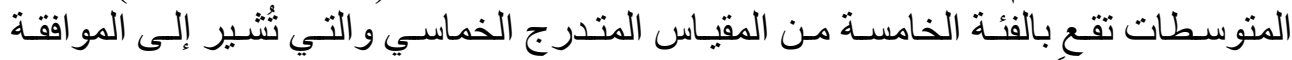
بدرجة كبيرة جداً.

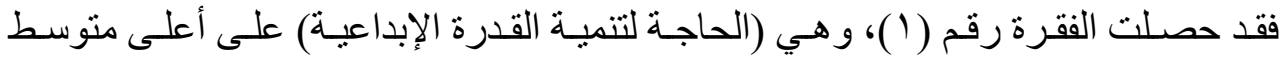

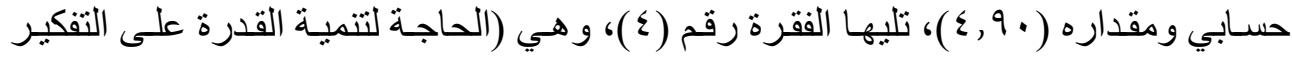

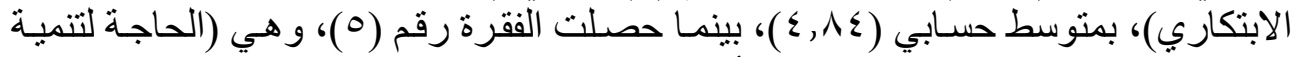

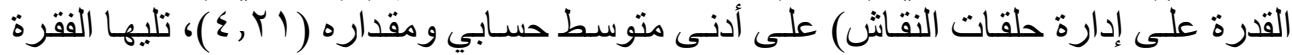

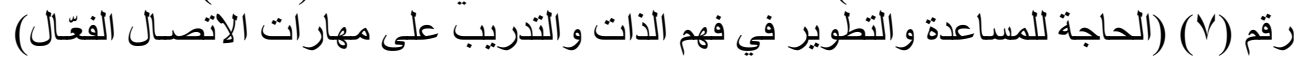

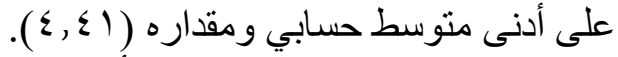

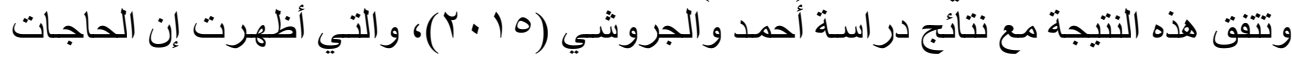

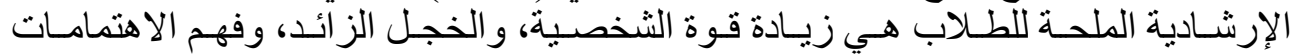

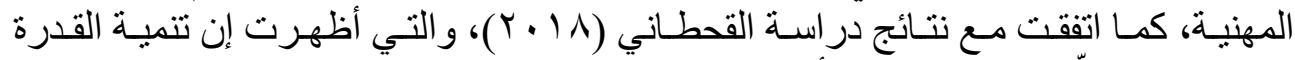

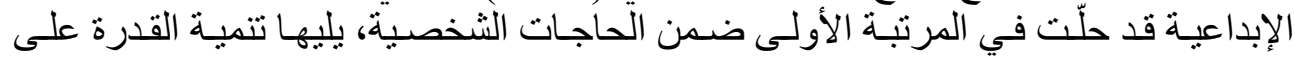
الأهداف المستقبلية. 


\section{الاحتياجات الإرشادية للمو هوبين في الجامعات.}

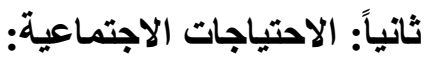

جدول (^) استجابات أفراد عينة الدراسة على الفقرات المتعلقة بالاحتياجات الاجتماعية

\begin{tabular}{|c|c|c|c|c|c|}
\hline المو افقة & الترتيب & الانحر اف المعياري & الحسابي & 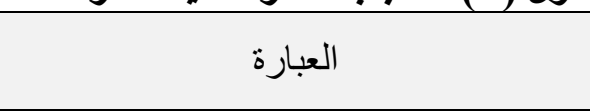 & b \\
\hline كبيرة & r & 1, or & $\varepsilon, 1 \varepsilon$ & الحاجة لتنمية القدرة على مو اجهة المشكلات & $\wedge$ \\
\hline كبيرة & 7 & 1, 1, & $r, q \leq$ & الحاجة لتنمية القدرة على العمل الجماعي & 9 \\
\hline كبيرة & $\varepsilon$ & $1,1 v$ & r, १V & الحاجة لتنمية القدرة على المبادرة & 1 . \\
\hline كبيرة & $\wedge$ & $1, r \vee r$ & T, $\uparrow \varepsilon$ & الحاجة لتتمية القدرة على تكوين علاقات & 11 \\
\hline كبيرة & V & $1, Y \vee T$ & $r, v)$ & الحاجة لتنمية القدرة على التفاعل الاجتماعي & ir \\
\hline كبيرة - كبرة & 0 & $1,1 \times \wedge$ & $r, 97$ & الحاجة لتنمية قيم التسامح مع الآخرين & $1 r$ \\
\hline 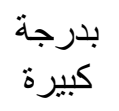 & r & $1, .01$ & $\varepsilon, 1 \Gamma$ & الحاجة للتشجيع على تقديم المساعدة لمن & $1 \leq$ \\
\hline كبيرة & 1 & $\cdot, \wedge \leqslant 7$ & $\varepsilon, \varepsilon V$ & الحاجة إلى اكتساب المهار ات التو افقية، & 10 \\
\hline \multicolumn{2}{|c|}{ بدرجة كبيرة } & $\cdot 9 \leq 1$ & $r, 99$ & \multicolumn{2}{|l|}{ المتوسط الحسابي العام } \\
\hline
\end{tabular}

* المتوسط الحسابي من 0 درجات.

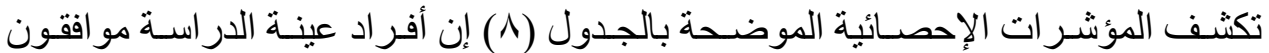

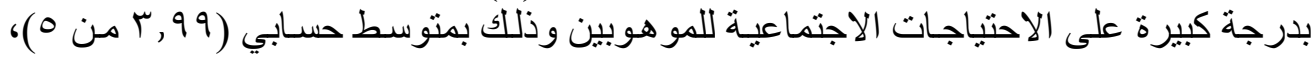

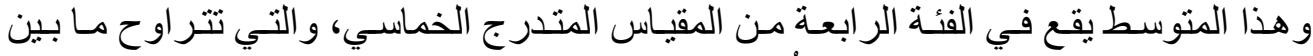

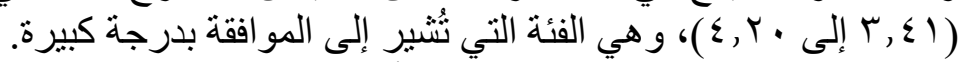

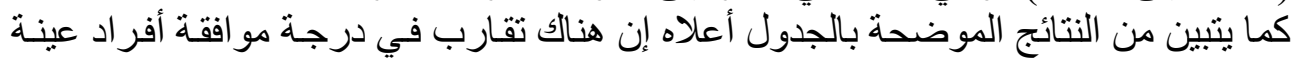

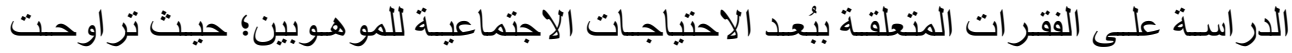

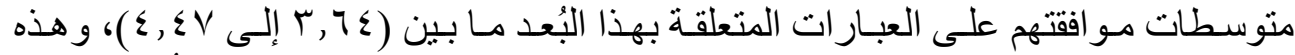

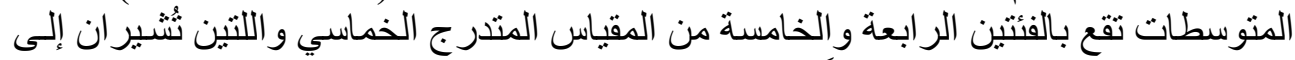
الموافقة بدرجة (كبيرة، كبيرة جداً). 
فقد حصلت الفقرة رقم (0 1) )، وهي (الحاجة إلى اكتساب المهار ات التو افقية، وكيفيـة التعامل وهل

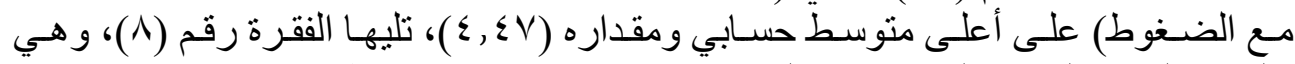

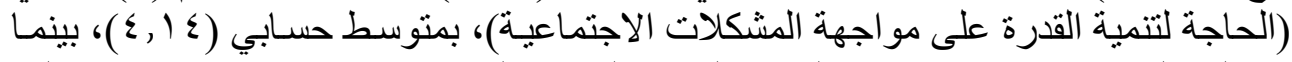

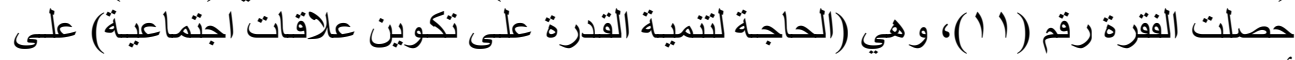

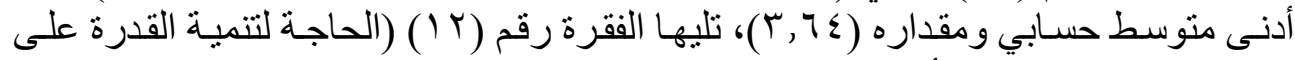

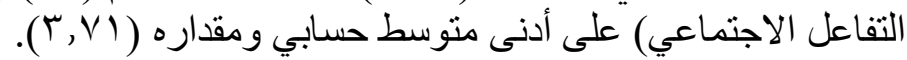

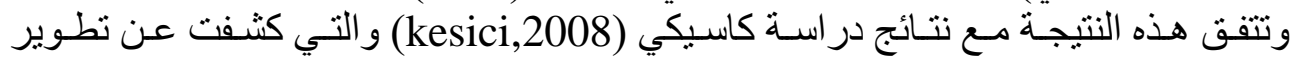

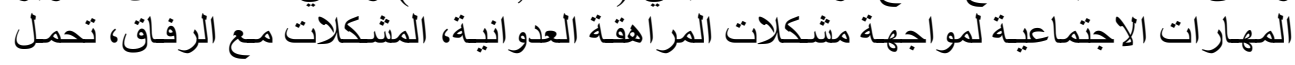

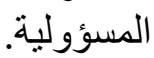

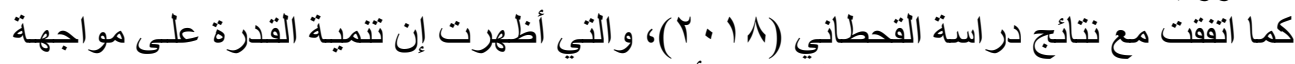

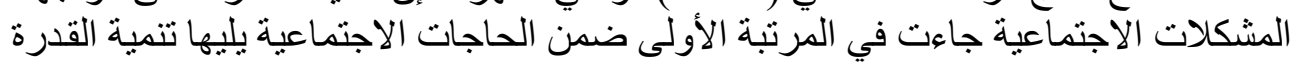

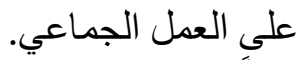

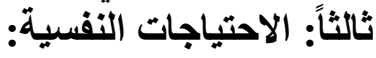

جدول (9) استجابات أفراد عينة الدراسة على الفقرات المتعلقة بالاحتياجات النفسية

\begin{tabular}{|c|c|c|c|c|c|}
\hline ال المو افقة & الترتيب & 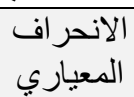 & الحستوسط & 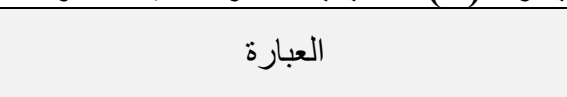 & r \\
\hline بدرة كبيرة & $r$ & $\cdot, \wedge \vee \neg$ & $\varepsilon$, Or & الحاجة إلى احتر ام الأسئلة والأفكار & 17 \\
\hline بدرجة كبيرة & $\varepsilon$ & $\cdot, \wedge \leqslant \vee$ & $\varepsilon, 0$. & الحاجة لتتمية مستوى الطموح & iv \\
\hline بدارة كبيرة & 0 & $\cdot, \wedge 71$ & $\varepsilon, \varepsilon V$ & الحاجة لتنمية القدرة على مو اجهة الضغوط & 11 \\
\hline بدرة كبيرة & 1 & $\cdot, 9 \wedge \wedge$ & $\varepsilon, \varepsilon Y$ & الحاجة لتنمية مسنوى مفهوم الذات & 19 \\
\hline بدرجة كبيرة & 1. & 1, rqr & $r, 97$ & الحاجة لتنمية مستوى الثعور بالأمن & r. \\
\hline بدرجة كبيرة & $\Lambda$ & $1,1 \cdot v$ & $\varepsilon, 10$ & الحاجة لتنمية القدرة على التحكم في الإنفعالات & YI \\
\hline بدرجة كبيرة & 9 & $1, r \wedge 0$ & $\varepsilon, \cdot r$ & 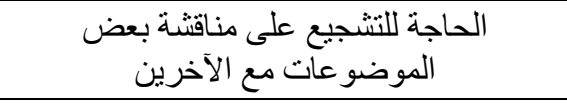 & Yr \\
\hline بدرجة كبيرة & 1 & $\cdot, \times \vee 1$ & $\varepsilon, 70$ & الحاجة إلى الاعتر اف بالمو اهب و القدرات & rr \\
\hline بدرة كبيرة & r & - VAY & $\varepsilon, 00$ & الحاجة إلى الاستبصار الذاتي بالاستعداد & $Y \varepsilon$ \\
\hline
\end{tabular}




\begin{tabular}{|c|c|c|c|c|c|}
\hline المو افقة & الترتيب & الالحير افي & الحسابي & 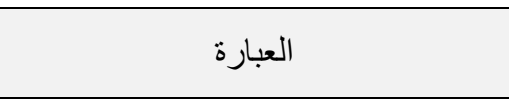 & p \\
\hline بدرجة كبيرة & v & $1,1 \leq \wedge$ & $\varepsilon, Y)$ & الحاجة إلى الاستقلالية والحرية في التعبير & ro \\
\hline بدرجة كبيرة & 11 & $1, \varepsilon \circ r$ & $r, \wedge \vee$ & الحاجة إلى الشعور بالأمن و عدم التهديد & r \\
\hline كبيرة جداً & بدر & $\cdot, \lambda \leqslant r$ & $\varepsilon, \Gamma$. & \multicolumn{2}{|l|}{ المتوسط الحسابي العام } \\
\hline
\end{tabular}

* المتوسط الحسابي من 0 درجات.

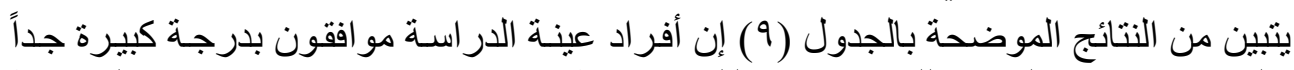

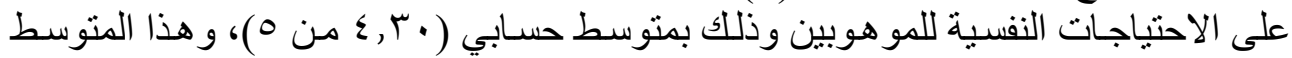

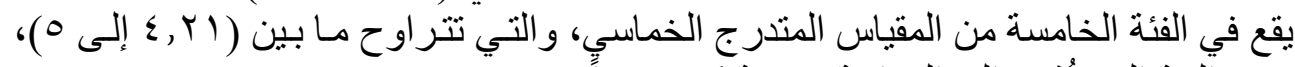

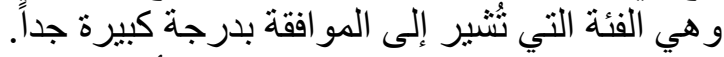

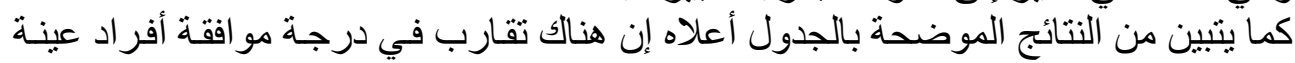

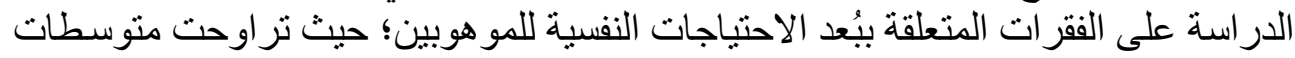

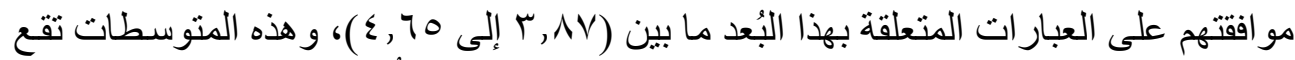

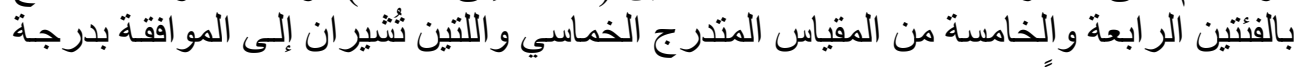
(كبيرة، كبيرة جداً).

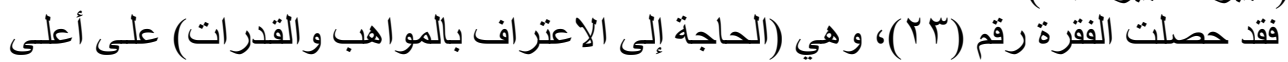

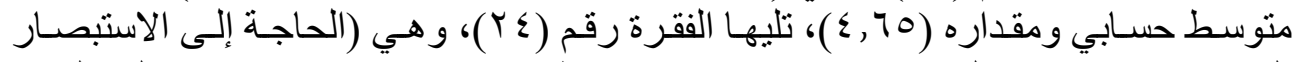

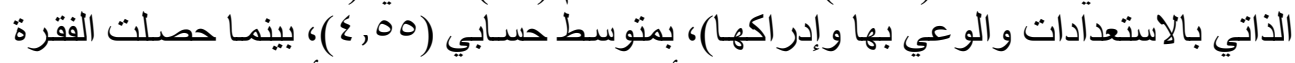

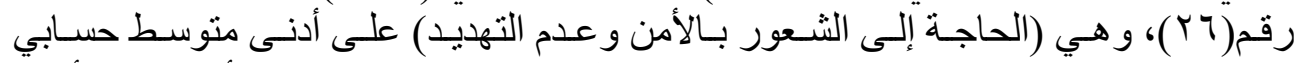

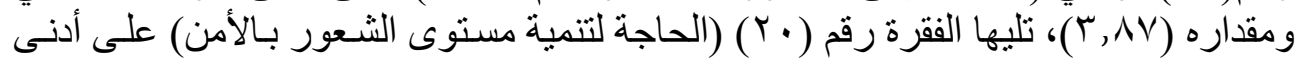
منوسط حسابي ومقداره (r, 97 (ب).

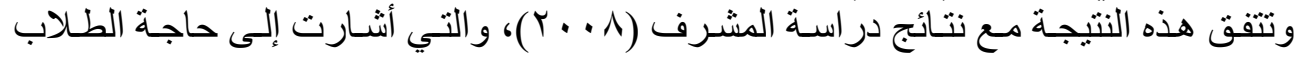

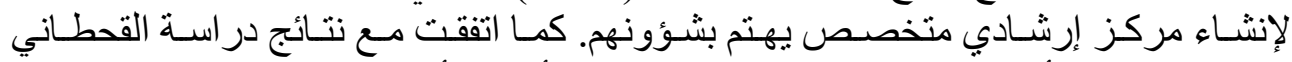

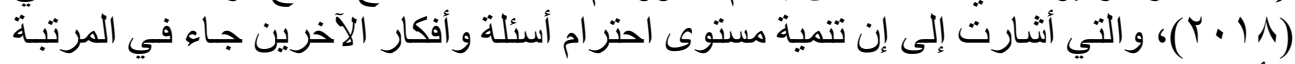

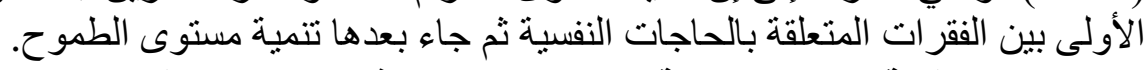

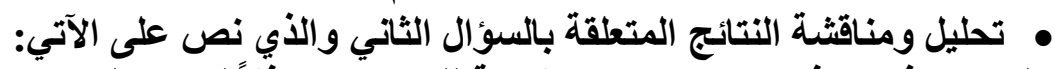

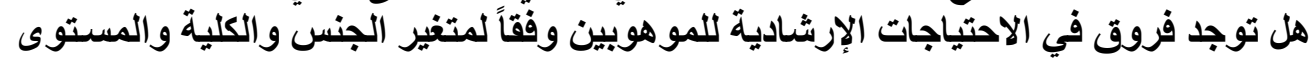
الاكاديمي? 


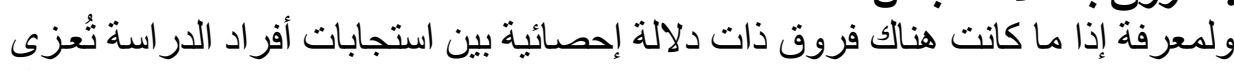

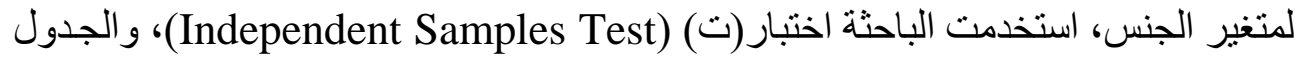
رقم (• (1) بوضنح ذللك:

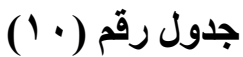

اختبار (ت) لتوضيح الفروق بين استجابات أفراد عينة الدراسة باختلاف الجنس

\begin{tabular}{|c|c|c|c|c|c|c|c|c|}
\hline \multicolumn{2}{|c|}{ مستوى الدلالة } & درجة الحرية & قيمة ت & المعياري & الحستبي & العدد & الجنس & أبعاد الدراسة \\
\hline \multirow{2}{*}{ غالة } & \multirow[b]{2}{*}{ • } & \multirow[b]{2}{*}{ T17 } & \multirow[b]{2}{*}{$\vee \wedge \wedge .-$} & $\cdot, \varepsilon \wedge$ & $\varepsilon, 7$. & $1 V \varepsilon$ & ذكر & \multirow{2}{*}{ اللثخصية الليات } \\
\hline & & & & $\cdot, \sum 71$ & $\varepsilon, T \leqslant$ & $1 \leq \varepsilon$ & أنثى & \\
\hline \multirow[b]{2}{*}{ دالة* } & \multirow[b]{2}{*}{,$\ldots$} & \multirow[b]{2}{*}{$M_{1} \leq}$. & \multirow[b]{2}{*}{$\begin{array}{c}- \\
\vee, \leftarrow \wedge q\end{array}$} & $\cdot, 9 \vee V$ & $r, T V$ & $I V \varepsilon$ & ذكر & \multirow{2}{*}{ الاحتياجات اللمو هوبين } \\
\hline & & & & $\cdot, V \leq 7$ & $\varepsilon, r q$ & $1 \leq \varepsilon$ & أنثى & \\
\hline \multirow{2}{*}{ دالة* } & \multirow{2}{*}{$\cdot, \cdots$} & \multirow{2}{*}{$r q \vee, 1 \leq \Lambda$} & \multirow{2}{*}{$\begin{array}{c}- \\
V, Y q \Lambda\end{array}$} & $\cdot, 91 \wedge$ & $\varepsilon, \cdot Y$ & IV & ذكر & \multirow{2}{*}{ النفسية للمو هو بين } \\
\hline & & & & $\cdot, 0 \wedge r$ & $\varepsilon, 7 \varepsilon$ & $1 \leqslant \varepsilon$ & أنتى & \\
\hline \multirow{2}{*}{ دالة* } & \multirow[b]{2}{*}{$\cdot, \ldots$} & \multirow{2}{*}{ r. } & \multirow{2}{*}{7,709} & $\cdot, V \backslash V$ & $\varepsilon, 1$. & $I V \varepsilon$ & ذكر & \multirow{2}{*}{ للإلإرشنادية } \\
\hline & & & & $\cdot, 0 . V$ & $\{, 0\}$ & $1 \leqslant \varepsilon$ & أنتى & \\
\hline
\end{tabular}

*دالة عند مستوى دلالة 0 . , • فأقل.

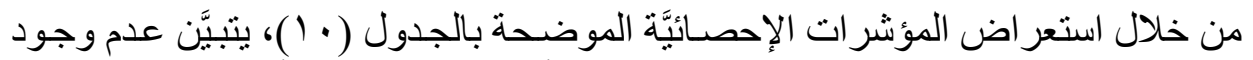

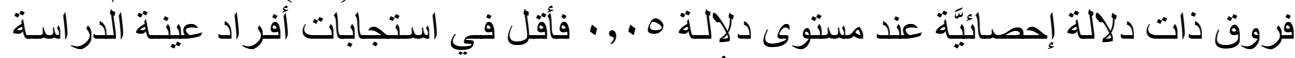

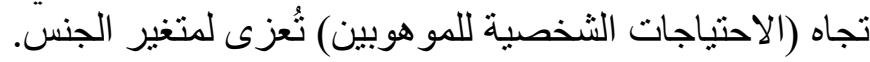

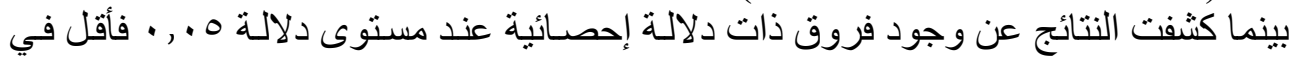

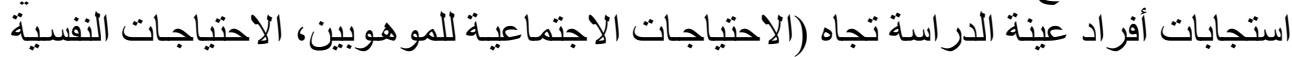

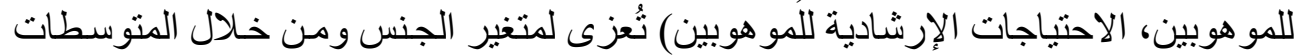

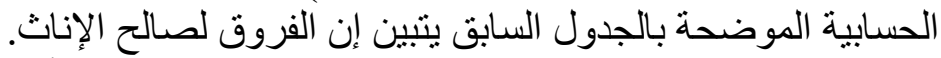

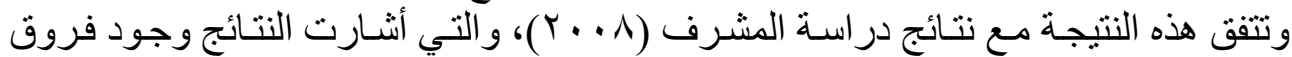

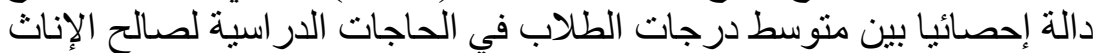

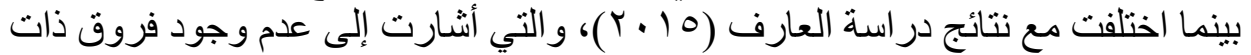

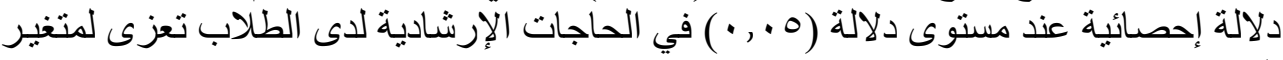




\section{ثانياً: الفروق باختلاف الكلية}

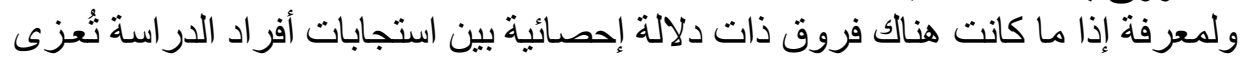

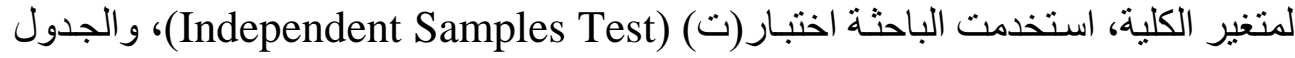

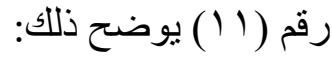

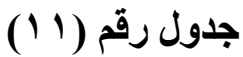

اختبار (ت) لتوضيح الفروق بين استجابات أفراد عينة الدراسة باختلاف الكلية

\begin{tabular}{|c|c|c|c|c|c|c|c|c|}
\hline \multicolumn{2}{|c|}{ مستوى الدلالة } & درجة & قيمة ت & الاتحراف & المتوسط & العدد & الكلية & أبعاد الدراسة \\
\hline \multirow{2}{*}{ غالة } & \multirow{2}{*}{$\cdot, \cdot 71$} & \multirow{2}{*}{ TIT } & \multirow{2}{*}{$\overline{-}$} & $\cdot, \varepsilon \vee \uparrow$ & $\varepsilon, 7$. & r\A & علمية & \multirow{2}{*}{ اللثخصية اللمونية } \\
\hline & & & & $\cdot, \leq \Gamma \leq$ & $\varepsilon, V T$ & 0. & كليات & \\
\hline \multirow{2}{*}{ دالة* } & \multirow{2}{*}{$\cdot, \ldots$} & \multirow{2}{*}{$\Lambda r, r \cdot r$} & \multirow{2}{*}{$\varepsilon, 179$} & $\cdot, 971$ & $r, 9 r$ & r71 & كليات & \multirow{2}{*}{ الإجتماعية الإجنات } \\
\hline & & & & $\cdot, v \leq q$ & $\varepsilon, \varepsilon r$ & 0. & كليات & \\
\hline \multirow{2}{*}{ دالة* } & \multirow{2}{*}{$\cdot, \cdots$} & \multirow{2}{*}{$\wedge q, \cdot r r$} & \multirow{2}{*}{$\varepsilon, \cdot r \varepsilon$} & • • & $\varepsilon, Y \varepsilon$ & r71 & كليات & \multirow{2}{*}{ للاحتياجات النفسية } \\
\hline & & & & $\cdot, 7) \wedge$ & $\varepsilon, 70$ & 0. & كليات & \\
\hline \multirow{2}{*}{ دالة* } & \multirow{2}{*}{$\cdot, \cdots$} & \multirow{2}{*}{$\Lambda V, \Sigma \vee Y$} & \multirow{2}{*}{$\varepsilon, \bar{Y} \odot 9$} & $\cdot, 7 \wedge \varepsilon$ & $\varepsilon, Y_{0}$ & r71 & كلية & \multirow{2}{*}{ الإحتياجات } \\
\hline & & & & - , $\leqslant 99$ & $\varepsilon, 7$. & 0. & كليات & \\
\hline
\end{tabular}

*دالة عند مستوى دلالة 0 . , • فأقلّ.

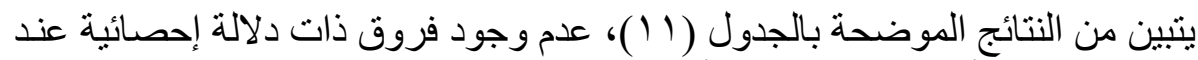

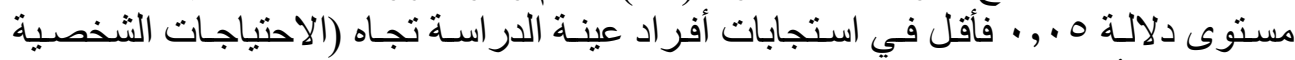
للمو هوبين) تُعزى لمتنغير الكلية.

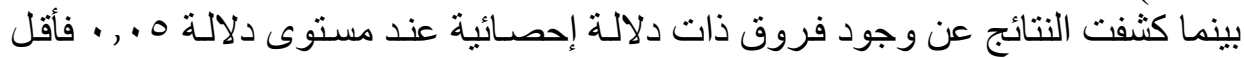

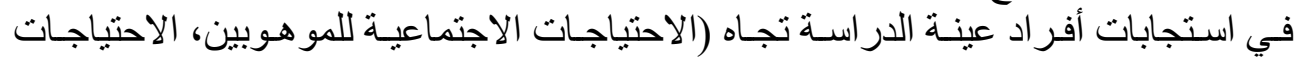

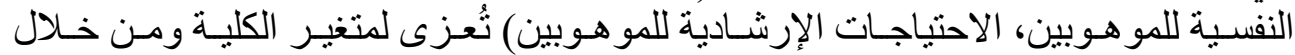

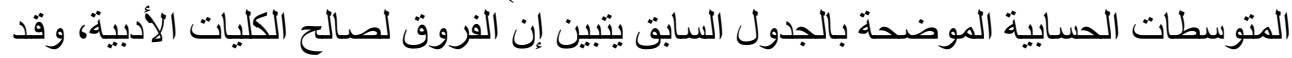

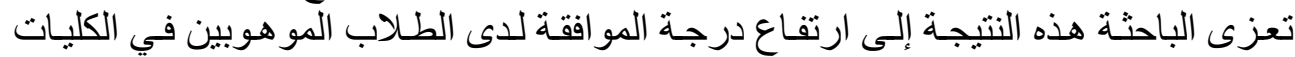

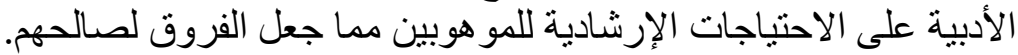




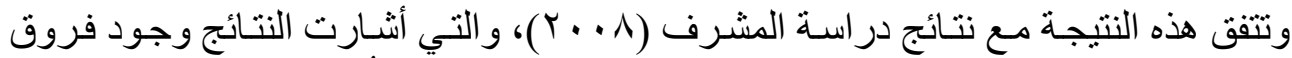

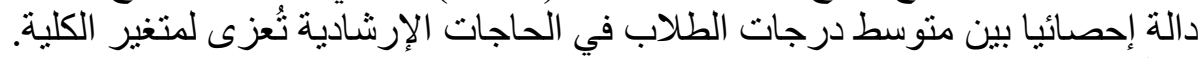
ثالثاً: الفروق باختلاف المستوى الأكاديمي:

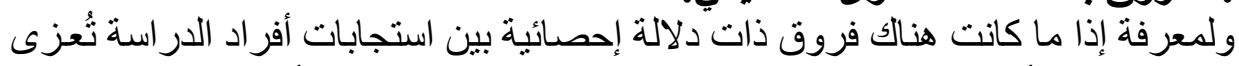

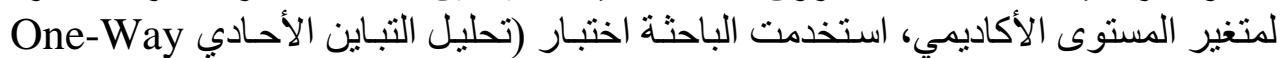

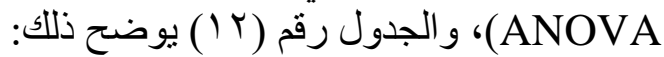

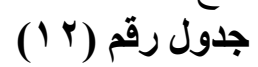

نتائج تحليل التباين الأحادي (ف) لتوضيح الفروق بين استجابات أفراد الدراسة باختلاف

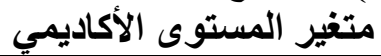

\begin{tabular}{|c|c|c|c|c|c|c|c|}
\hline \multicolumn{2}{|c|}{ مستوى الدلالة } & قيمة ف & المر بعات & لدرجات & المربعوع & المجموعات & أبعاد الدر اسة \\
\hline \multirow{2}{*}{ دالة* } & \multirow{2}{*}{$\cdot, \cdots \wedge$} & \multirow{2}{*}{$r, 9 \times 1$} & דצד. & 7 & $\Gamma, \wedge \backslash \wedge$ & بين المجمو عات & \multirow{3}{*}{ الاحتياجات الشخصية } \\
\hline & & & YIE. & إ & $77,7) V$ & داخل المجمو عات & \\
\hline & & & & MIV & $v \cdot, \varepsilon \Gamma_{0}$ & المجموع & \\
\hline \multirow{2}{*}{ دالة* } & \multirow{2}{*}{$\cdot, \cdots 7$} & \multirow{2}{*}{$r, \wedge r$} & r, 770 & 7 & $10,99$. & بين المجمو عات & \multirow{3}{*}{ الاحتياجات الإجتماعية } \\
\hline & & & 19. & וा & $r \neg \Lambda, q \cdot v$ & داخل المجمو عات & \\
\hline & & & & MIV & $\nmid \wedge \varepsilon, \wedge ૧ \vee$ & المجموع & \\
\hline \multirow{2}{*}{ دالة } & \multirow{2}{*}{$\cdot, \cdots \wedge$} & \multirow{2}{*}{$r, q \wedge \varepsilon$} & $r, \cdot r V$ & 7 & I T, Y & بين المجمو عات & \multirow{3}{*}{ الاحتياجات النفسية } \\
\hline & & & דヘr. & M & $r \mid r, T \leq r$ & داخل المجمو عات & \\
\hline & & & & MV & YYE, OTV & المجموع & \\
\hline \multirow{2}{*}{ دالة* } & \multirow[t]{2}{*}{, . . } & \multirow[t]{2}{*}{ ו } & $1, \leqslant \vee T$ & 7 & $\Lambda, \wedge r V$ & بين المجمو عات & \multirow{3}{*}{ الاحتياجات الإرشادية } \\
\hline & & & $\varepsilon Y q$. & MI & . . . & داخل المجمو عات & \\
\hline & & & & MIV & $1 \leqslant Y, r T V$ & المجموع & \\
\hline
\end{tabular}

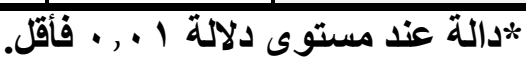

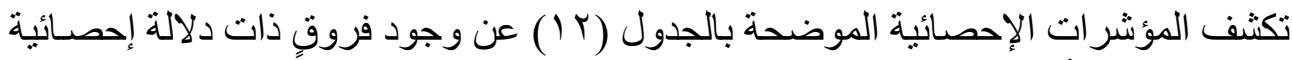

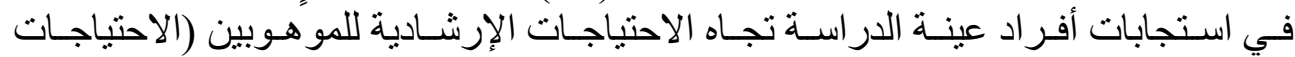

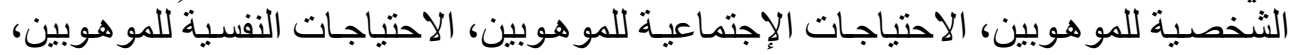

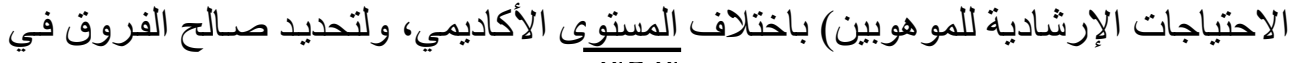


كل فئة من فئات المستوى الأكاديمي؛ استخدمت الباحثة اختبار "شيفيه"، وجاءت النتائج كمـا

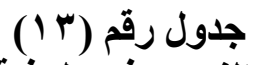

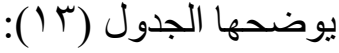

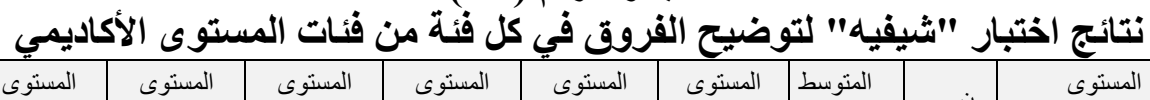

\begin{tabular}{|c|c|c|c|c|c|c|c|c|c|c|}
\hline ماجستير & المستوى & السادستوى & الخامستوى & الرستوى & الثنالث & الثنانتي & الحسابي & ن ن & الأكاديمي & الدراسة \\
\hline & & & & & & - & $\varepsilon, \leqslant 9$ & 1. & المستوى الثاني & \multirow{7}{*}{ اللاحتخبية } \\
\hline & $*_{\cdot}, \varepsilon \cdot r$ & $*_{\cdot}, Y \wedge \wedge$ & $*,, Y, O$ & & - & & $\varepsilon, V Y$ & 01 & المستوى الثالث & \\
\hline & & & & - & & & $\varepsilon, 74$ & ir. & المستوى الر ابع & \\
\hline & & & - & & $*, r q r$ & & $\{, 0\}$ & 71 & الخامستوى & \\
\hline & & - & & & $*,, Y \wedge \Lambda$ & & $\varepsilon, \varepsilon 9$ & $r$. & المستوى السادس & \\
\hline & - & & & & $* \cdot, \varepsilon \cdot r$ & & $\varepsilon, r V$ & r. & المستوى السابع & \\
\hline \multirow[t]{6}{*}{-} & & & & & & & $\varepsilon, 7 \varepsilon$ & ir & ماجستير & \\
\hline & & & & & & - & $r, \lambda$. & 1. & المستوى الثاني & \multirow{7}{*}{ الالاجتماعية } \\
\hline & *., & & & & - & & $\varepsilon, \cdot V$ & 01 & المستوى الثالث & \\
\hline & $* \cdot, V \leq 4$ & $*_{\cdot}, \leq 0$. & $*$, HTA & - & & & $\varepsilon, 11$ & ir. & المستوى الر ابع & \\
\hline & & & - & *., TrA & & & $\Gamma, \wedge_{0}$ & 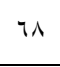 & الخامستوى & \\
\hline & & - & & $*_{.}, \leq 0$. & & & $r, v r$ & $r$. & المستوى السادس & \\
\hline$*_{-}, \wedge \vee O_{-}$ & - & & & $* \cdot, V \leq 7$ & דוד, .* & & $r, \varepsilon \leqslant$ & $r$. & المستوى السابع & \\
\hline \multirow[t]{4}{*}{-} & $*_{-} \cdot, \wedge \vee O_{-}$ & & & & & & $\varepsilon, \Gamma$ & ir & ماجستير & \\
\hline & & & & & & - & $\{, 10$ & 1. & المستوى الثاني & \multirow{7}{*}{ للالمو هوبينة } \\
\hline & & & & & - & & $\varepsilon, Y \uparrow$ & 01 & المستوى الثالث & \\
\hline & *org. & $*_{0},\{07$ & $*_{.}, Y V \varepsilon$ & - & & & $\varepsilon, \varepsilon \vee$ & Ir. & المستوى الر ابع & \\
\hline$*_{-}$OVY.- & & & - & *YY & & & $\varepsilon, r$. & 71 & الخامستوى & \\
\hline$*_{-} v 00 .-$ & & - & & $* \leqslant 07$ & & & $\varepsilon, \cdot r$ & $r \cdot$ & المستوى السادس & \\
\hline$*_{-} \wedge r V .-$ & - & & & *orq. & & & $r, 90$ & $r$. & المستوى السابع & \\
\hline \multirow[t]{3}{*}{-} & $*_{-}, \lambda r V_{-}$ & $*_{-}$, Y $000_{-}$ & $*_{-}$, OVY & & & & $\varepsilon, V Y$ & ir & ماجستير & \\
\hline & & & & & & - & $\varepsilon, 1 \leqslant$ & 1. & المستوى الثاني & \multirow{2}{*}{ الالاحتشادية الإدوبية } \\
\hline & $*_{1},\{01$ & & & & - & & $\varepsilon, r V$ & 01 & المستوى الثالث & \\
\hline
\end{tabular}


مج (7) - (7) (19) يناير r.r.

المجلة العربية لعلوم الإعاقة والموهبة

\begin{tabular}{|c|c|c|c|c|c|c|c|c|}
\hline & *.,OYY & *. & $*, r$ r & - & & $\varepsilon, \varepsilon \varepsilon$ & ir. & المستوى الر ابع \\
\hline & & & - & $*, r$, rq & & $\varepsilon, r$. & 14 & الخامستوى \\
\hline$*_{-},, \leq q V_{-}$ & & - & & זדז, •* & & $\varepsilon, \cdot \wedge$ & $r$. & المستوى السادس \\
\hline$*_{-}$, , TON_ & - & & & *.,OYr & $*_{-},\{\leqslant 0\}_{-}$ & r, qr & $r$. & المستوى السابع \\
\hline - & $*_{-},, 70 \Lambda_{-}$ & $*_{-} \leqslant 9 \vee .-$ & & & & $\varepsilon, 01$ & Ir & ماجستير \\
\hline
\end{tabular}

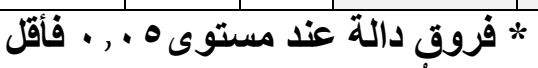

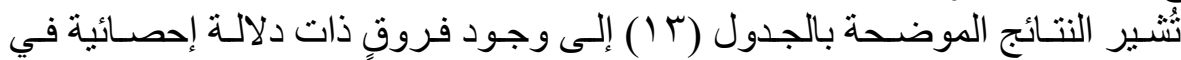

استجابات أفر اد عينة الدر اسة تجاه الاحتياجات الإرشادية للمو هوبينٍ (الاحتياجـات الثخصية

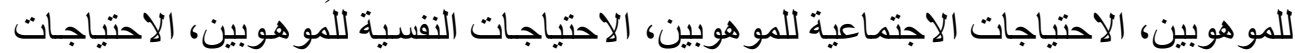

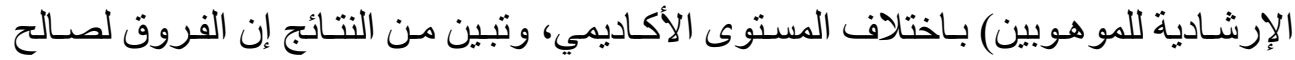

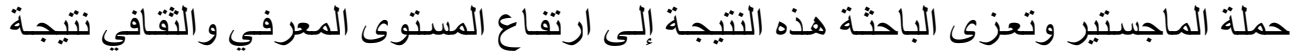

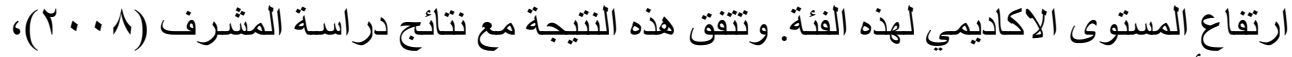

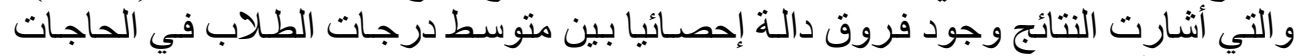

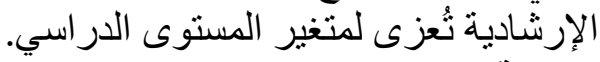
خلاصة التنائسج:

كثنفت النتائج إن أفر اد عينـة الدراسـة موافقون بدرجـة كبيرة جداً على طبيعـة الاحتياجـات

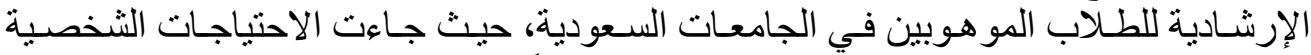

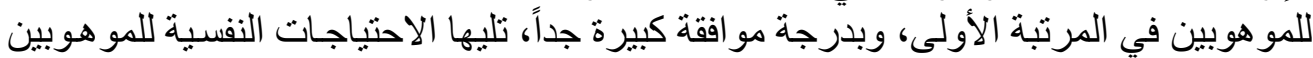
وبدرجة مو افقة كبيرة جداً، بينما جاءت الاحتياجات الاجتماعية للمو هوبين في المرتبـة الأخيرة

وبدرجة مو افقة كبيرة.

أوضحت النتائج إن أفراد عينة الدراسة مو افقون بدرجة كبيرة جداً على الاحتياجـات الشخصية

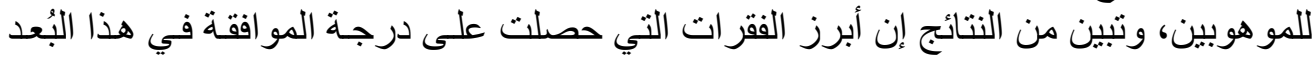
هي (الحاجة لتنمية القدرة الإبداعية، الحاجة لتنمية القدرة على التفكير الابتكاري).

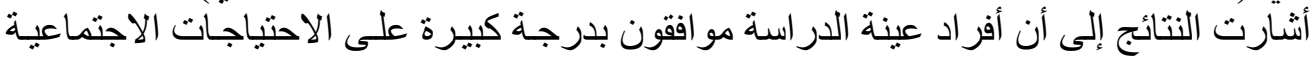

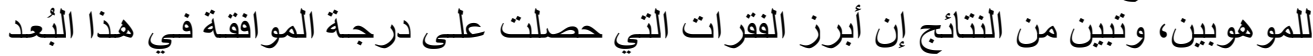

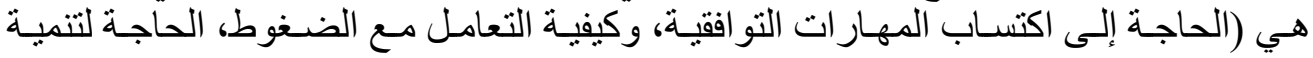
القدرة على مو اجهة المشكلات الاجتماعية).

أوضحت النتائج إن أفر اد عينـة الدراسـة موافقون بدرجـة كبيرة جداً على الاحتياجـات النفسية

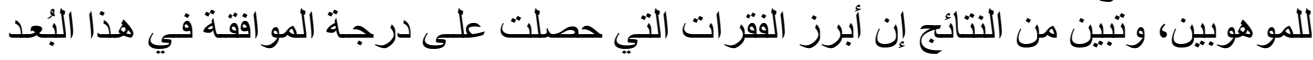
هي (الحاجة إلى الاعتر اف بالمواهب والقدر ات، الحاجة إلى الاستبصـار الذاتي بالاستعدادات و الوعي بها و إدر اكها). 


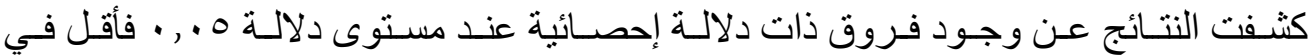

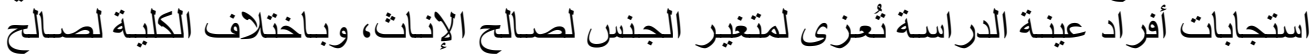

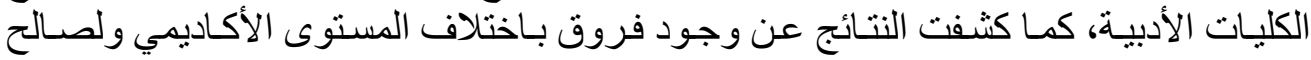
حملة الماجستير.

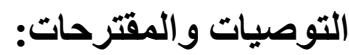

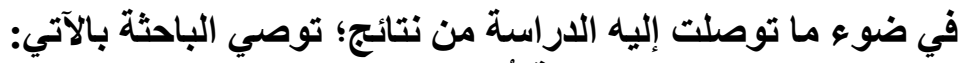

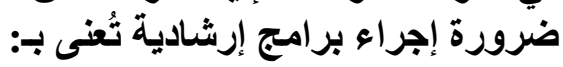

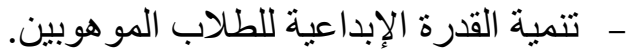
- تلتمية القدرة على التفكير الابتكاري.

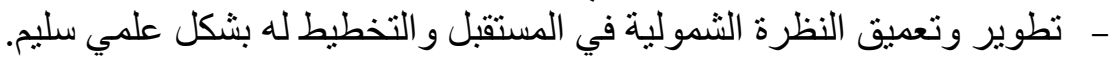

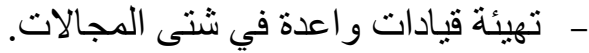

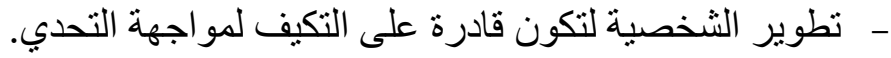

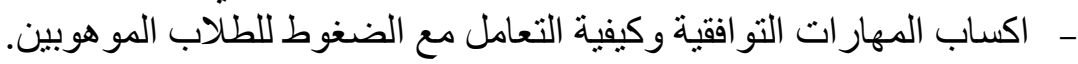
- تنمية القدرة على مواجهة المشكلات الاجتماعية.

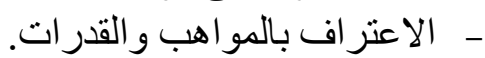

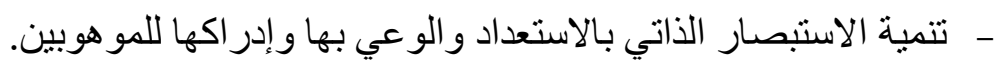

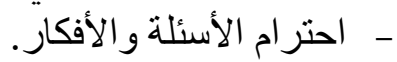

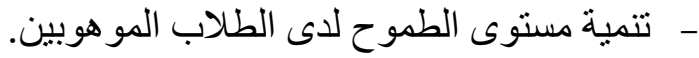

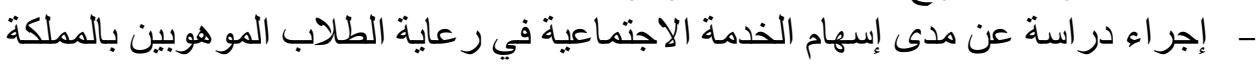
العربية السعودية. 


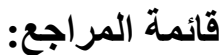

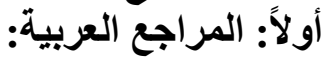

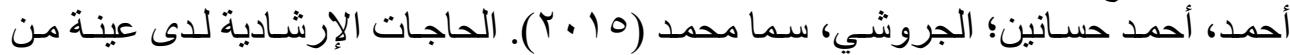

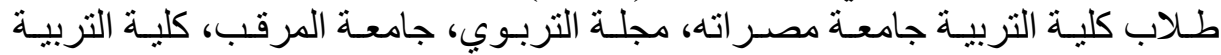

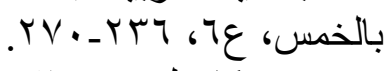

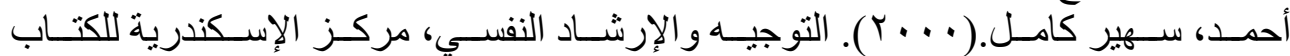

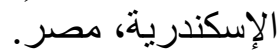

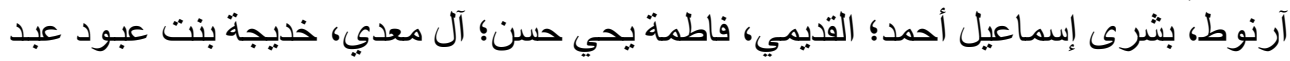

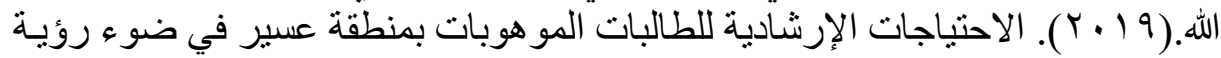

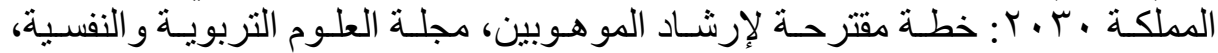

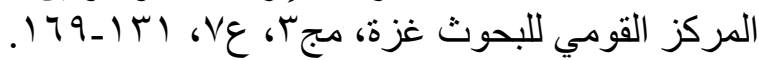

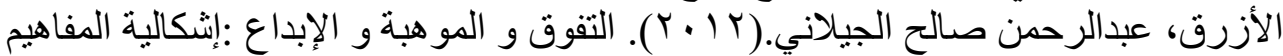

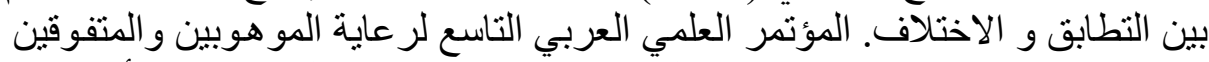

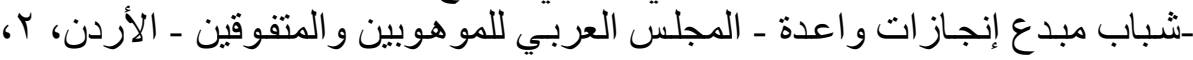

$$
191-170
$$

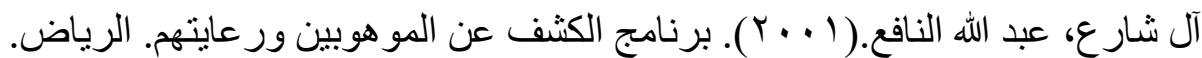

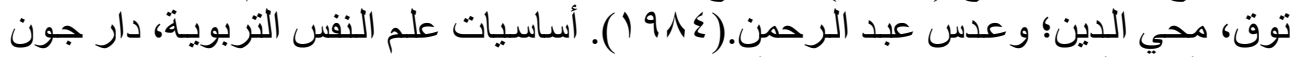

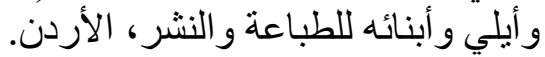

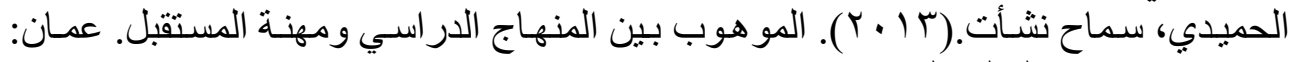
مركز ديبون لتعليم التفكير.

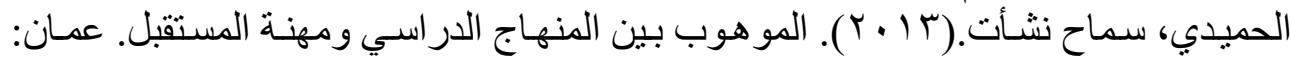
مركز ديبون لتعليم التفكير.

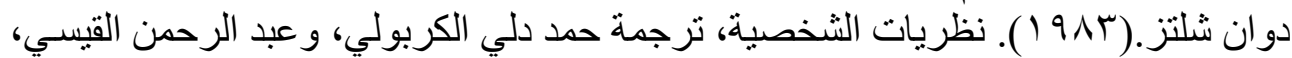
مطبعة جامعة بغداد.

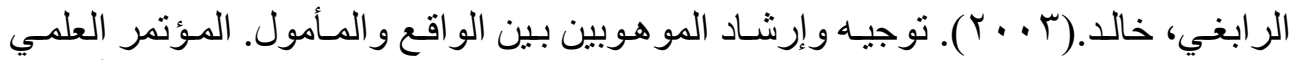

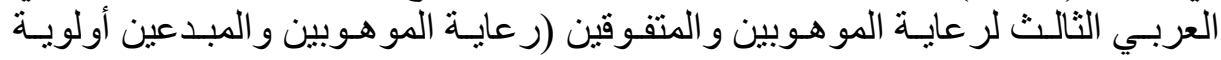

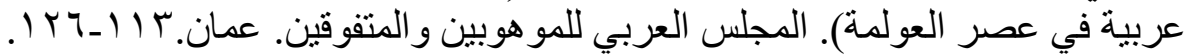

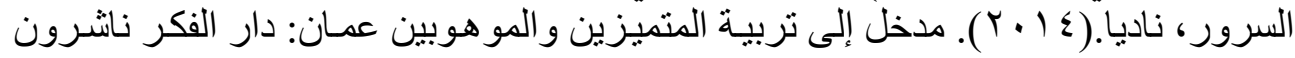
وموزعون.

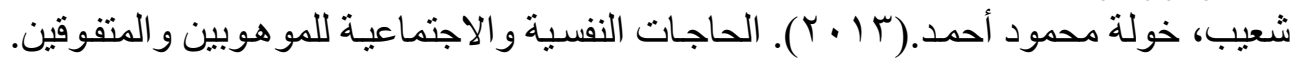
عمان: مركز ديبونو لتعليم التفكير. 
الطنطاوي، رمضان عبد الحميد.(9 ؟ ( هـ). المو هوبون أساليب رعايتهم و أساليب تدريسهم، الأردن، عمان: داري، ردفان الثقافة.

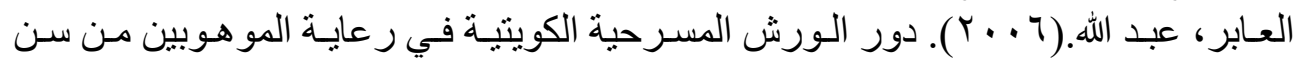

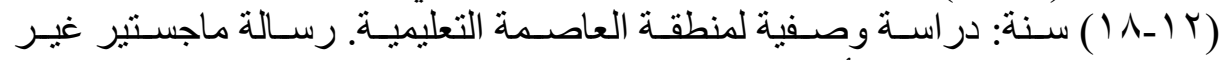
منشورة، جامعة البلقان، الأردن.

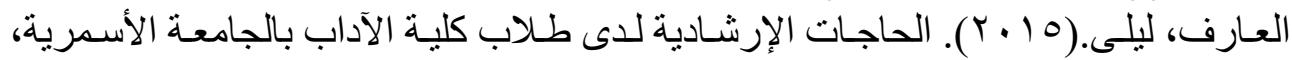

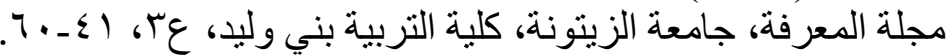

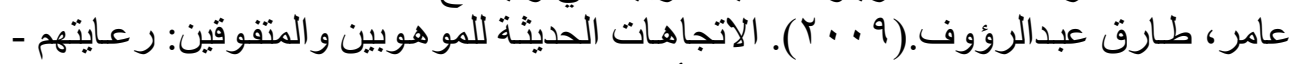

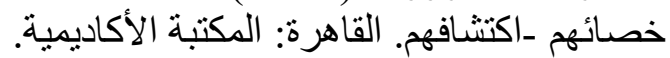

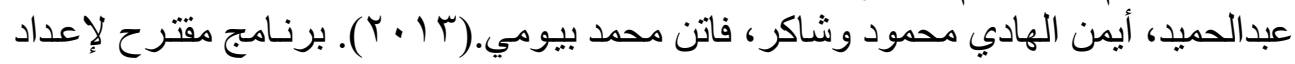

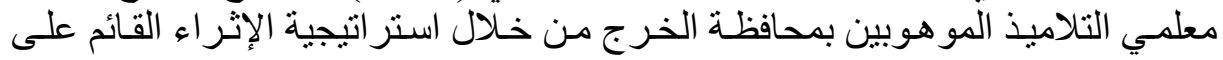

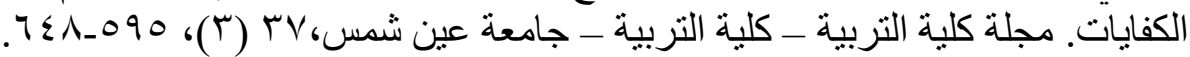

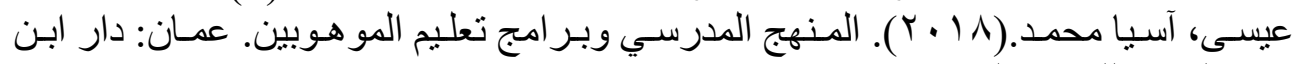

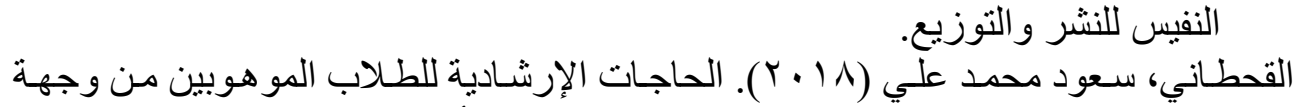

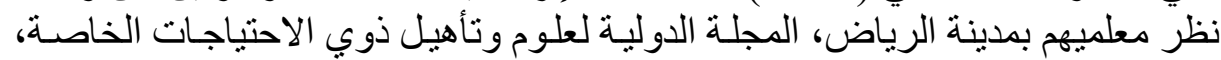

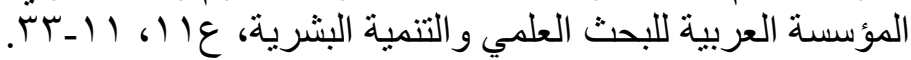

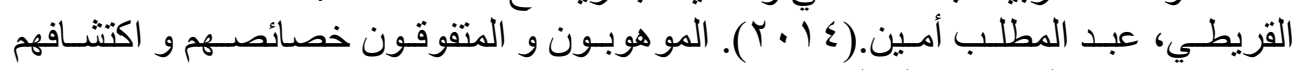

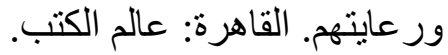

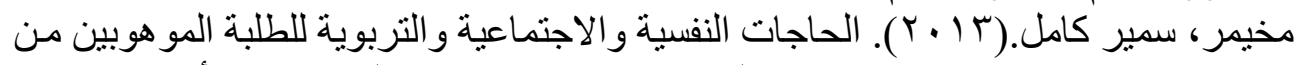

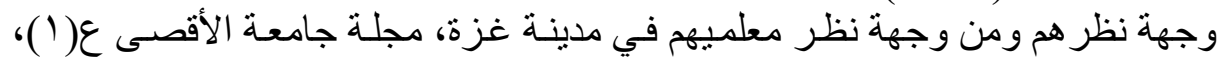

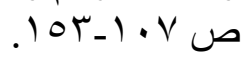

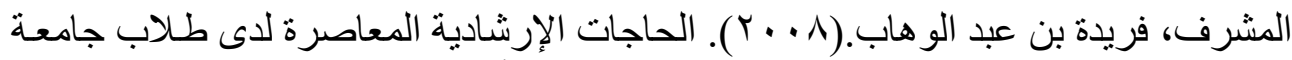

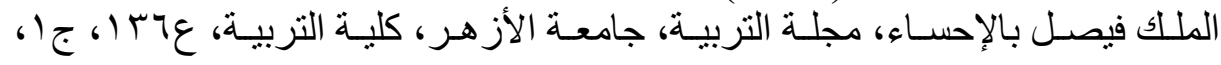
YrO-191

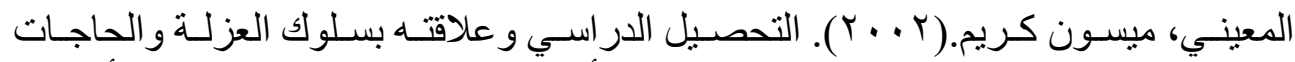

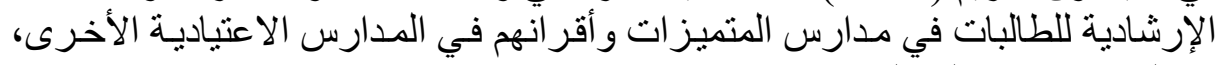

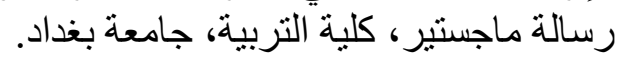

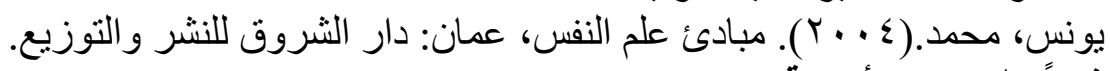

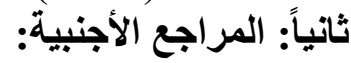
Atik,G.Yalcin.(2010).Counseling needs of educational sciences students 
at the Ankara university. Procardia social and behavior sciences 2, 1520-1526.

Botella , M ., F€Urst , G ., Myszkowski , N ., Storme , M \& Luminet , O . ( 2015 ) . French Validation of the Overexcitability Questionnaire 2 : Psychometric Properties and Factorial Structure . Journal of Personality Assessment , 97 ( 2 ) , 209-220

Kesici, S. (2008). Sixth, Seventh, and Eight- Grade Students' Guidance and Counseling Needs According to Parents' Views. Eurasian Journal of Educational Research, Vol (32). Pp ( 101- 116). 
